NBER WORKING PAPER SERIES

\title{
ICT USE IN THE DEVELOPING WORLD: AN ANALYSIS OF DIFFERENCES IN COMPUTER AND INTERNET PENETRATION
}

\author{
Menzie D. Chinn \\ Robert W. Fairlie \\ Working Paper 12382 \\ http://www.nber.org/papers/w12382
NATIONAL BUREAU OF ECONOMIC RESEARCH
1050 Massachusetts Avenue
Cambridge, MA 02138
July 2006

We thank Thomas Wu for helpful comments, Tanapong Potipiti for assistance in collecting and compiling data, and Hiro Ito for providing data. Financial support of UW and UCSC faculty research funds, and a grant from the NET Institute, is gratefully acknowledged. The views expressed herein are those of the author(s) and do not necessarily reflect the views of the National Bureau of Economic Research.

(O2006 by Menzie D. Chinn and Robert W. Fairlie. All rights reserved. Short sections of text, not to exceed two paragraphs, may be quoted without explicit permission provided that full credit, including $\odot$ notice, is given to the source. 
ICT Use in the Developing World: An Analysis of Differences in Computer and Internet

Penetration

Menzie D. Chinn and Robert W. Fairlie

NBER Working Paper No. 12382

July 2006

JEL No. O30, L96

\begin{abstract}
$\underline{\text { ABSTRACT }}$
Computer and Internet use, especially in developing countries, has expanded rapidly in recent years. Even in light of this expansion in technology adoption rates, penetration rates differ markedly between developed and developing countries and across developing countries. To identify the determinants of cross-country disparities in personal computer and Internet penetration, both currently and over time, we examine panel data for 161 countries over the 1999-2004 period. We explore the role of a comprehensive set of economic, demographic, infrastructure, institutional and financial factors in contributing to the global digital divide. We find evidence indicating that income, human capital, the youth dependency ratio, telephone density, legal quality and banking sector development are associated with technology penetration rates. Overall, the factors associated with computer and Internet penetration do not differ substantially between developed and developing countries. Estimates from Blinder-Oaxaca decompositions reveal that the main factors responsible for low rates of technology penetration rates in developing countries are disparities in income, telephone density, legal quality and human capital. In terms of dynamics, our results indicate fairly rapid reversion to long run equilibrium for Internet use, and somewhat slower reversion for computer use, particularly in developed economies. Financial development, either measured as bank lending or the value of stocks traded, is also important to the growth rate of Internet use.
\end{abstract}

Menzie D. Chinn

Robert M. LaFollette School of Public Affairs

Department of Economics

University of Wisconsin

1180 Observatory Drive

Madison, WI 53706-1393

and NBER

mchinn@lafollette.wisc.edu

Robert W. Fairlie

Department of Economics

University of California

Santa Cruz, CA 95064

rfairlie@ucsc.edu 


\section{Introduction}

The rapid diffusion of computers and Internet use has been a fixture of the global landscape over the past decade; nonetheless, rates of technology use still differ markedly across countries. For example, the latest estimates from the International Telecommunications Union (ITU) indicate that only 3 percent of the population in India used the Internet in 2004 . In contrast, more than 50 percent of the population in all developed countries used the Internet, with rates of technology use being substantially higher in many European and North American countries. These disparities in technology diffusion may have important economic consequences because technology use may increase knowledge diffusion through improving communication efficiency (e.g. Jovanovic and Rob, 1989), improve political engagement (Norris, 2001), increase productivity (Brynjolfsson and Hitt, 2003, Dedrick 2003), and allow developing countries to "leapfrog" traditional methods of increasing productivity (Steinmueller, 2003).

The importance of ICT diffusion in developing countries to economic advancement has been stressed in the policy arena and previous literature (Wallsten 2005). For developed economies, the literature is fairly well developed, while the implications for developing countries are only now being explored in a systematic fashion. To the extent that the pace of economic growth is dependent on the rate of ICT diffusion, we believe it is important to examine the factors that hinder the uptake of new ICT's. ${ }^{1}$

Several previous studies have examined the causes of computer and Internet penetration rate differences across countries. Many studies find a strong positive relationship between technology use and income across countries and within countries (see Quibria, et al. 2003, OECD 2001, and U.S. Department of Commerce 2002 for example), while some point to other factors - such as telecommunications access and pricing and regulatory effectiveness - as being of major importance (Dasgupta, et al. 2001, Mann et al. 2000 and Wallsten 2005). In an earlier extensive cross-country analysis of personal computer adoption, Caselli and Coleman (2001) explore the determinants of the computer imports/worker ratio, which is their proxy measure for the investment in ICT data, from 89 countries over the years 1970-90. ${ }^{2}$ The three notable variables than enter with statistical significance are openness to imports from OECD countries,

\footnotetext{
${ }^{1}$ See OECD (2006). Policy declarations motivated by these concerns include statements at the 2003 UN/ITU World Summit on the Information Society, http://www.itu.int/wsis/docs/geneva/official/dop.html.

${ }^{2}$ See also Pohjola (2003) for an analysis of the determinants of ICT investment for a sample of 49 countries from
} 
the level of educational attainment, and the index of property rights. More recently, Chinn and Fairlie (2006) examine the determinants of cross-country differences in computer penetration across a panel of 100 countries over the 1999-2001 period. Income per capita, years of schooling, illiteracy, youth and aged dependency ratios, the urbanization rate, telephone density, electricity consumption, and regulatory quality are found to have statistically significant relationships with computer penetration rates.

Although the Internet is a more recent technological innovation, a few studies have examined cross-country differences. Kiiski and Pohjola (2002) examine Internet hosts per 1000 inhabitants from 1995-2000 for a broad sample encompassing about sixty OECD and developing countries. ${ }^{3}$ They find that the five year growth in this variable is related to income per capita, telephone access costs, and the average years of schooling. Chinn and Fairlie (2006) also examine cross-country differences in Internet penetration in 1999-2001, and find that they are associated with income per capita, the dependency ratio, electricity consumption and regulatory quality. A few studies have focused on specific groups of countries or regions of the world (see APEC 2002, Estache, et al. 2002, Mann and Rosen 2001, Oyelaran and Oyeyinka 2003, Liu and San 2003, and Wong 2002). Focusing on a panel of 45 developing countries in 2001, Wallsten (2005) examines the determinants of Internet use. He finds that Internet use is negatively associated with regulations, measured as whether ISPs are required to get formal regulatory approval, and generally positively associated with per capita income and telephone mainlines.

Although a few recent studies have focused on the topic, technology use in developing countries is a fast moving target. For example, estimates from the ITU reported below indicate that Internet penetration rates for developing countries have increased seven-fold since their 1999 levels, with some countries such as China increasing more than ten-fold. The surge in computer and Internet trends in the past few years is not specific to developing countries as technology use rates are considerably higher now than they were just a few years ago for almost every country in the world. Another limitation of the previous research is that there is no comprehensive empirical study of technology use in developing countries that includes a large number of developing countries and includes an extensive set of controls for economic,

1993-2000. He finds positive effects for income and human capital, and negative effects for agricultural share.

${ }^{3}$ See also Dasgupta, et al. (2001) for an earlier analysis of cross-country differences in growth rates in the Internet to telephone mainlines ratio and Hargittai (1999) for an earlier analysis of cross country differences in per-capita Internet hosts. 
demographic, infrastructure, institutional and financial variables. We also contribute to the literature by providing the first estimates of the importance of financial openness and quality of access to financial capital in explaining computer and Internet penetration rates, and the first detailed analysis of the determinants of the rapid growth rates in technology that have occurred over the past several years. Finally, we undertake a systematic analysis of the relative importance of different factors in contributing to the differences across developing countries using a technique commonly used to decompose earnings gaps between groups (Blinder, 1993 and Oaxaca, 1993). To be sure, Chinn and Fairlie (2006) estimate decompositions with their panel of countries from 1999-2001, but the focus is on world-wide regional differences and not specific countries or developing countries. To our knowledge, there are no systematic crosscountry econometric analyses of the determinants of PC and Internet use focused on developing countries using data from the past few years in which technology penetration rates have exploded.

The decomposition analysis will allow us to directly address several issues that have been discussed in the literature. One key question is the relative importance of income in explaining differences across developing countries. Another set of questions are prompted by findings in the recent growth literature that highlight the roles of human capital and institutional factors. The channels through which these factors affect growth are difficult to discern, but it is likely that both exert at least some influence on the rate at which new technologies are adopted. Hence, the first question is how important is human capital for creating demand for information and communication technology services? Computers may require substantial levels of education for use, but telephones and the Internet may require very little, according to Dasgupta, et al. (2001). Another question pertains to the impact of institutional regimes. Do factors such as legal protections and regulatory quality matter even after accounting for income? Wallsten (2005), among others, has focused on this issue. It is possible that these institutional aspects are important factors in limiting ICT penetration among developing countries, but without a careful analysis of all of the factors simultaneously we cannot identify their relative importance. This is extremely important because it answers the question of how scarce resources should be allocated along each of these fronts. We also suspect that openness to international trade, capital and intellectual flows are also important for increasing ICT use in developing countries. But, in this case there is very little empirical evidence. Hence, as a policy question we do not know how 
much emphasis should be placed upon opening up countries to FDI, versus opening up trade in ICT goods and services, versus other avenues of liberalization.

To conduct this analysis we take several steps. First, we estimate panel data regression models relating levels of computer and Internet penetration to economic, demographic, infrastructure, institutional and financial factors using the last three years of available data (200204). Second, we examine whether the determinants of IT penetration differ between developing and developed countries. Third, we use a decomposition technique to identify the causes of differences between specific developing countries and our benchmark, the developed country average. Estimating the decomposition separately by country allows us to identify whether the reasons for low rates of IT penetration differ between developing countries such as China, India and Mexico. Finally, we explore the determinants of cross-country differences in rates of technology diffusion focusing on developing countries. This last step is important because static analysis may miss important aspects of the technology diffusion, which is first and foremost a dynamic process. This issue may be particularly important if at any given time, some countries are away from their respective long run equilibrium levels of technology penetration.

\section{Data}

Data on technology use and telecommunications are from the International Telecommunications Union's (ITU) World Telecommunication Indicators Database. The data are obtained primarily through annual questionnaires administered by the Telecommunications Development Bureau (BDT) of the ITU. Supplemental information is obtained from reports from telecommunication ministries, regulators, operators, and ITU staff. Detailed data are available on telephone, personal computer, Internet, and other telecommunications and electronics use. The ITU data also contain detailed information on telephone costs.

Computer and Internet penetration rates analyzed below are derived from the number of personal computers and Internet users per 100 people. These measures of technology use from the ITU are the only ones available for a large number of countries over the past several years. However, they may suffer from three notable limitations. First, the number of personal computers may understate the total use of computers in some countries in which mainframe computers are prevalent (World Bank 2002). This is probably less of a concern, however, focusing on more recent data with the rise of networked PCs. Second, there is no information on 
the quality of computers. ${ }^{4}$ Cross-country differences in the quality and number of high-quality computers per person are likely to be large and possibly larger than simple counts of the number of computers. Finally, the number of Internet users is based on reported estimates of users, derivations from reported Internet Access Provider (ISP) subscriber counts, or calculated by multiplying the number of Internet hosts by an estimated multiplier. Thus, Internet use may be understated, particularly in developing countries where many commercial subscribers rent computers connected to the Internet (World Bank 2002). ${ }^{5}$

The primary source for data on demographics, income, and other variables included in the regression analysis is the World Bank's World Development Indicators database. We also use indices of rule of law and regulatory quality drawn from the World Bank's Governance Indicators database. The construction and attributes of these indicators are described in much greater detail in Kaufmann, Kraay and Mastrizzi (2003). Our primary measure of human capital, average years of schooling, is derived from the World Bank's Edstats.

The impact of financial development is incorporated in a variety of ways. The first variable we examine is a traditional measure, the ratio of private credit from deposit money banks to the private sector, representing the overall development in the banking sector. We also use an equity market variable, namely the ratio to GDP of the total value of stocks traded. We draw the series from the database constructed by Beck, Demirgüc-Kunt, and Levine (2000), as extended and updated by Hiro Ito.

We incorporate a role for openness not only to trade flows, but also to capital flows. To this end, we rely upon the capital account openness index, which we term financial openness, developed by Chinn and Ito (forthcoming). This index is the first principle component of four IMF binary variables relating to restrictions on cross-border transactions, including on the capital account. To the extent that the stringency of the capital controls is correlated with restrictions on the other categories, this variable measures the intensity of capital controls. More details on all variables included in the analysis are provided in the Appendix.

\footnotetext{
${ }^{4}$ Hence, we only examine the extensive margin of technology diffusion. In contrast, Comin et al. (2006) have stressed the dynamics of the intensive margin.

${ }^{5}$ Estimates of the number of Internet hosts in a country may also have measurement problems because they are based on country codes and do not necessarily capture the physical location of the host. Furthermore, hosts that do not have a country code are assigned to the United States (Wallsten 2005).
} 


\section{Cross-Country Differences in Computer and Internet Penetration Rates}

Computer and Internet use has grown rapidly over the past decade. As depicted in Figure 1, there were only 4.2 personal computers per 100 people in the world in 1995. By 2004, the number of computers per 100 people had climbed to more than 12. Internet use grew even faster. In 1995 less than 1 percent of the world's population used the Internet. By 2004, 13.7 percent of the world's population used the Internet.

In the past decade, technology use has risen from being concentrated among an extremely small subset of the population in developing countries to a much large share of the population. In 1995, there were only 6 computers per 1,000 people and 4 Internet users per 10,000 people in developing countries. The computer/population ratio climbed to 3.7 computers per 100 people and the percent of the population using the Internet grew to nearly 6 percent by $2004 .{ }^{6}$ The growth in the Internet even over the past five years is remarkable -- only 0.8 percent of the population in developing countries used the Internet in 1999. Developed countries also experienced rapid increases in the past decade in technology use. By 2004, there were 57 computers and 52 Internet users per 100 people in developing countries, compared to 20 computers and 4 Internet users per 100 people a decade earlier.

Technology use has increased rapidly among several large developing countries. Figures 3 and 4 report computer and Internet penetration rates for the eight largest developing countries, China, India, Indonesia, Brazil, Pakistan, Bangladesh, Nigeria and Mexico. Computer and Internet penetration rates have grown so rapidly in Mexico and Brazil that for both countries rates exceed 10 percent. China has also increased from computer and Internet penetration rates of essentially zero in 1995 to 4.1 and 7.2 percent in 2004, respectively

Although computer and Internet use has expanded rapidly in developing countries in the past few years, a large digital divide continues to exist between the developed and developing world. ${ }^{7}$ Table 1 reports estimates of computer and Internet penetration rates by type of country and for the largest developing countries in 2004 , which is the latest year of available data from

\footnotetext{
${ }^{6}$ Higher rates of Internet use than computers per capita in developing countries may be due to the preponderance of Internet cafes in many of these countries (Wallsten 2004, 2005).

${ }^{7}$ Fink and Kenny (2003) note that growth rates in Internet use per capita have been higher in poor countries than those in wealthy countries, and thus the digital divide is shrinking. Given the large differences that exist today, it may be a considerable amount of time before we witness convergence in Internet use. They also point out that the digital divide is not apparent when Internet use is normalized by GDP rather than population. We retain our focus, however, on the conventional per capita measures of ICT use, and identify how much of the gap is explained by income differences in a multivariate analysis.
} 
the ITU. Relative to developed countries in which there are 0.57 computers per person and half of the population uses the Internet, developing countries have a long way to go to close the gap. As noted above, there are 3.7 computers per 100 people and less than 6 Internet users per 100 people in developing countries.

Most developing countries have substantially lower rates of computer and Internet penetration than the rates for developed countries. Rates of technology use are especially low in African countries. For example, in Ethiopia there are 0.31 computers and 0.16 Internet users per 100 people. On the other hand, some developing countries have much higher rates. Malaysia has computer and Internet penetration rates of 19.2 and 38.6 percent. Among larger developing countries Brazil, Mexico and Iran have relatively high computer rates, and Argentina, Turkey and Mexico have relatively high Internet rates. Overall, the estimates reported in Table 1 indicate that there exists a substantial amount of variation in rates of technology use between developed and developing countries and even across the set of developing countries.

\section{The Determinants of Computer and Internet Use}

\subsection{Empirical Model of Computer Use}

The basic framework for analyzing the use of personal computers and the Internet is simply a demand and supply one. Demand is driven by consumers and firms, whereas supply is driven by a few countries that export the bulk of equipment (for computer use) and many firms in all countries (for Internet providers). In the case of computers, they represent a derived demand, insofar as firms are concerned; and a final demand for consumers. For firms, the marginal product of ICT equipment is a function of the demand for the final good produced, which will be correlated with income per capita. The "after-tax" price of goods sold will also depend upon how burdened firms are by regulations; inefficiently implemented regulations, or regimes where expropriation is the norm, will reduce the expected return to investing in capital of all sorts, and hence reduce the derived demand for ICT equipment.

The productivity of ICT equipment depends upon the attributes of the labor stock if labor and ICT equipment are complements. Hence, the stock of human capital, measured by either years of schooling, or the illiteracy rate, should be important. Another complementary input is power consumption; clearly a PC is of limited use without adequate or consistent power supply. Of course, after some threshold of connectivity or power level, ICT equipment and electricity 
might be substitutes. Finally, the productivity of a computer might be enhanced by telephone access. Telecommunications infrastructure might then be another complementary input.

Income is likely to be a key determinant of the consumer demand for computers. It has an effect on consumers' budget constraints, and it may also affect preferences for owning a computer, especially in the sense of "keeping up with the Joneses." Income may be especially important in the presence of liquidity constraints. Although some consumers may view computers as a worthwhile investment they may not be able to finance the purchase of one. Preferences for owning a computer are also likely to vary across individuals and may depend on exposure to and the perceived usefulness of owning a computer. This may be related to a person's income, education level, age, presence of children, and urban/rural location (see Fairlie 2004 and Ono and Zavodny 2006 for example).

To estimate the demand function, one would need to be able to identify some exogenous variables in the supply equation. In the case of computers, one candidate variable is obvious the price of computers. On a global scale, this appears to be driven by exogenous forces (Moore's Law) at the level of analysis we are concerned with. An examination of the hedonic price indices calculated for ICT equipment in the US provides forceful evidence for large movements in the relative price of computing power. Indeed, Pohjola (2003) uses the US price of computing equipment as the price of computers in all economies he studies. Since this price index looks very similar to a (downward sloped) linear trend, it is not clear that in a structural setup, even one demand parameter could be identified (especially if there are deterministic time trends in the demand function). Consequently, we rely upon a reduced form estimation procedure, and assume that we cannot identify the underlying structural parameters.

Specifically, we estimate several reduced-form equations for computer penetration rates that include four main sets of independent variables. The first set includes conventional infrastructure variables, such as main telephone lines per capita, two measures of Internet access costs (monthly telephone subscription charges and the cost of a three minute call), and electricity consumption. ${ }^{8}$ The second set includes demographic variables, such as shares of the population below 14 and above 65, and the share of the population in urban centers. The third set includes economic variables, such as income per capita and human capital (measured either as years of

\footnotetext{
${ }^{8}$ Unfortunately, we do not have a measure of the percent of the population with access to electricity. Instead, we use per capita electricity consumption as a proxy.
} 
schooling or the illiteracy rate). The fourth category includes measures of institutional quality or policy, such as explicit measures of legal system quality or trade openness. The latter can be construed as an economic characteristic, but it is often viewed as an indicator of how high trade barriers are. And, because trade barriers tend to be correlated with other domestic impediments to commerce, trade openness is often taken to be an indicator of a less regulated business environment. The fifth category includes financial variables such as the economy's openness to capital flows, as well as levels of financial market development.

We hypothesize that many of the same factors are likely to influence country-level Internet penetration rates. In particular, income, telecommunications infrastructure and costs, and legal quality may be especially important determinants of Internet use. We include the same set of regressors in the reduced-form equations for Internet penetration rates.

We first turn to the results for computer penetration rates from 2002-04, which are reported in Table 2. In column (1), the results indicate that there are a number of clearly identifiable determinants of computer use. Unsurprisingly, income per capita comes in as a powerful determinant of $\mathrm{PC}$ use; each $\$ 1000$ increase in per capita income is associated with a 1.7 percentage point increase in the number of PCs per capita. ${ }^{9}$ Also not unexpectedly, human capital appears to be important. A one year increase in average schooling is associated with roughly a 1.5 percentage point increase in PC penetration. Recent research on the determinants of computer ownership using microdata also finds strong relationships between computer ownership, and income and education. The positive relationship between per capita income and computer penetration rates may be partly due to relaxing the budget constraint, changing preferences, or liquidity constraints.

One surprising result is the importance of telephone line density. A one percentage point increase in this variable is associated with a 0.3 percentage point increase in PC penetration. It is hard to interpret this result; it may be there are complementarities between computers and telephone lines. Telephone lines may be important for one of the most common uses of computers, accessing the Internet. Another explanation is that countries that have a well developed communication infrastructure are also likely to have other unobservable attributes that encourage PC use.

\footnotetext{
${ }^{9}$ Scatter plots of computer penetration rates and income reveal an approximate linear relationship.
} 
We also include measures of telephone costs in the computer penetration regression, mostly to retain the consistency of the specifications across the two types of technology. While telephone costs may affect computer adoption through Internet use, which is one of the main uses of personal computers, our estimates do not provide evidence of such a relationship. Both monthly telephone subscription charges and the cost of three minute local calls have statistically insignificant coefficients in the computer penetration regressions.

We do not find that higher rates of electricity consumption are associated with higher rates of computer penetration after controlling for other factors. This is somewhat surprising because access to electricity is essential for the use of personal computers. The reported specification includes a modified measure of electricity consumption in which values in excess of $6000 \mathrm{kWh}$ per capita are top coded at the value (which represents a clear breakpoint in the bivariate relationship), but an unmodified measure of electricity consumption also results in a negative and statistically insignificant coefficient estimate. The problem may be due to collinearity with income because we find that the two variables are strongly correlated and we find a positive and statistically significant coefficient estimate on our electricity consumption variable after removing income from the equation.

Demographic variables generally enter in with the expected signs. A higher proportion of youth is associated with greater rate of PC use. Children may generate a stronger demand for technology, especially for educational purposes. Although statistically insignificant at conventional levels, the point estimate for ages 65 and above is negative providing suggestive evidence that the elderly have a lower demand for technology either for personal use or because of absence from the labor force. The coefficient estimate on the percent of the population located in urban areas is negative and statistically insignificant at conventional levels.

In the next set of variables, we find that the rule of law is statistically insignificant. ${ }^{10}$ Openness to trade also enters the equation with a positive and statistically insignificant coefficient at conventional levels. Many previous empirical studies of growth find that openness to international trade is an important factor.

\footnotetext{
${ }^{10} \mathrm{We}$ also estimate a specification that includes a related measure -- regulatory quality. Fairlie and Chinn (2006) find using earlier data (1999-02) that regulatory quality has a positive and statistically significant relationship with computer penetration. Instead, we find a small negative and statistically insignificant coefficient for the 2002-04 period.
} 
We also include a few financial variables that have not been previously examined in this context. First, we include a measure of financial openness (see column 2). There appears to be no relationship between financial openness and computer penetration. We also include a measure of the development of the banking sector in the country. Specifically, we measure the ratio of private credit by deposit money banks and other financial institutions to GDP. The coefficient estimate on this variable is also small and statistically insignificant. In column (3), we replace this measure with the ratio of the total value traded on the stock market to GDP. The coefficient is positive, but statistically insignificant. Overall, the financial openness of the economy and level of internal financial development do not appear to be correlated with computer penetration after controlling for income and other factors.

To increase the sample size substantially, we exclude the telephone cost variables which are not statistically significant in any of the specifications (column 4). We also drop electricity consumption which is missing for many countries. The results for income, telephone density and youth are robust to increasing the sample of countries. The main change is that the coefficient on years of schooling is now smaller and statistically insignificant at conventional levels. We also try excluding average years of schooling and replacing it with the illiteracy rate (column 5). The illiteracy rate has a small and statistically insignificant coefficient.

\subsection{Internet Use}

We now take up the results for Internet penetration rates. To maximize comparability with the results for PC penetration rates, we retain the same basic set of regressors in our specifications. The Internet results are somewhat different than the computer results. Income has a smaller coefficient, but remains statistically significant. An increase of $\$ 1,000$ is associated with slightly less than a 1 percentage point increase in the Internet penetration rate in column (1). The same increase in income is associated with a larger, 1.7 percentage point, increase in the computer penetration rate. The finding is consistent with Internet service being relatively inexpensive compared to the cost of purchasing personal computers. This is especially true in some parts of the developing world where Internet cafes are an important source of access (Wallsten 2004, 2005). The association between Internet penetration and education is also weaker. In this case, the coefficient estimates are positive, but statistically insignificant in all specifications. The coefficient on illiteracy is positive, but statistically insignificant. 
Another difference in the results is that telephone density is not a statistically significant determinant of Internet use in some of the specifications. This is somewhat surprising given the statistically significant coefficient on this variable in the computer penetration regressions. We should note, however, that the telephone density is close to statistical significance in some of the specifications and is statistically significant in the final specification that includes a broader sample of 331 observations. By dropping the access costs and increasing the number of countries to include more developed countries in this specification, we are increasing the variability of telephone density so that this factor's signal to noise ratio is increased. The coefficient for this broader set of countries is not substantially different that the coefficient estimate for computer penetration. The smaller Internet penetration coefficient on telephone density may also be due to a non-linearity in the relationship that we are not capturing or the different ways of measuring the two dependent variables (i.e. Internet users vs. number of personal computers).

Some of the Internet results are surprising. Counter to the conventional wisdom, we find that the Internet access pricing proxies - the monthly telephone subscription charge and the average cost of a three minute local call - do not enter in with statistical significance. These results may differ from those reported in Dasgupta, et al. (2001) and Liu and San (undated) because we examine a more recent period (2002-2004), and a different sample of countries. In particular, the effect that Mann, Eckert and Knight (2000) identify - that high per minute charges may negatively affect Internet use more than high monthly subscription charge - may be swamped by other factors in our broader cross-country sample.

The demographic variables are not good predictors of Internet access, with the potential exception of the youth dependency ratio. Having a young population is associated with higher Internet penetration rates, but is statistically significant at conventional levels in only one of the reported specifications. The elderly population percent and urban percent have inconsistent signs across specifications and are statistically insignificant in all specifications.

The quality of legal institutions in a country is associated with Internet penetration. The coefficient estimate on rule of law is large and positive in all specifications and statistically significant in most specifications. ${ }^{11}$ Using the median reported coefficient estimate, a one standard deviation increase in rule of law is associated with a 5 percentage point increase in

\footnotetext{
${ }^{11} \mathrm{We}$ also try specifications with a measure of regulatory quality, but find statistically insignificant coefficients.
} 
Internet penetration. In contrast to these results, we find that trade openness is not statistically significant in its relationship with Internet penetration. The finding of a positive effect of trade openness in other studies may reflect the omission of a regulatory or legal policy variable such as the one we include in our regressions.

The estimates reported in Table 3 do not provide evidence that financial openness or the relative level of the stock market development matter for Internet penetration, but they do provide evidence that banking sector development is important. ${ }^{12}$ The coefficient on banking sector development is large and positive in all specifications and statistically significant in most specifications. The level of development of the banking sector may be important in providing loans to Internet providers and businesses needing to purchase IT equipment.

\subsection{Robustness Checks for Main Regressions}

To check the sensitivity of our results we conducted some robustness checks. We first estimate computer and Internet penetration regressions that include country fixed effects, to address the concern that there are unobserved country-level factors that may be correlated with some of the explanatory variables, thereby leading to biased coefficient estimates. Despite the brevity of the panel (which only includes three years), the results are somewhat informative, yielding estimates that are fairly similar to those obtained from the random effects model. In the computer penetration regressions, income and youth dependency have large positive coefficients, and the elderly percent has a negative effect. The main differences are that the coefficient on income is larger, the coefficient on telephone density is smaller and the coefficient estimate on years of schooling becomes implausibly large and negative (due to multicollinearity with the fixed effects). In the Internet regressions, income, rule of law, banking sector development and youth dependency have large positive coefficients. In these regressions, the coefficient on years of school is positive and also somewhat large. Overall, although the fixed effects estimates suffer from imprecision, they do not change our general conclusions regarding the determinants of computer and Internet penetration.

We also estimated models that weight countries by their population. In the weighted regressions, we continue to find large positive coefficients on telephone density, youth

\footnotetext{
${ }^{12}$ Other measures of stock market development were also tested. These include including stock market capitalization to GDP ratio, and the stock market turnover ratio.
} 
dependency, income and years of schooling in the computer regressions, and large positive coefficients on income, rule of law and banking sector development in the Internet regressions. The key changes are that years of schooling and telephone density generally exhibit stronger relationships in the weighted Internet regressions than in the original Internet regressions.

\subsection{Developing Countries}

Table 4 reports estimates of computer and Internet penetration regressions for developing countries. Estimates for all other countries are also reported for comparison. Overall, the factors associated with computer and Internet penetration do not differ substantially between developing countries and the rest of the world. In the computer regression for developing countries, telephone density, income and youth dependency have large positive coefficients. Compared to the set of other countries, some of these coefficients are smaller, but this is expected because the average computer penetration rate is much lower. The main difference in the computer results is that the education level is not associated with computer penetration. The lack of strength in this relationship is likely to be partly due to the removal of the largest source of variation in education levels (i.e. the difference between developing and developed countries). Similarly, the income coefficients are smaller in both subsamples than in the full sample.

In the Internet regressions, the coefficient estimate on income for developing countries is very similar to the coefficient estimate on income using the full sample (but is now statistically insignificant). We also find a roughly similar sized coefficient on rule of law and somewhat smaller coefficient on youth dependency. The level of banking sector development, however, does not enter in significantly.

Although we do not investigate these differences in detail, the main finding we draw from this analysis is that the factors associated with computer and Internet penetration do not differ substantially between developing and more developed countries. The factors that have weak or no relationships with technology adoption for the full sample of countries continue to have similar relationships. And, the most important factors associated with computer and Internet penetration in the full sample are generally the same ones for the developing world. The main problems arise from imprecise estimates resulting from removing a large number of observations and the variation between poor and wealthy countries. 


\section{Explanations for the Global Digital Divide}

\subsection{Methodology}

The regression analysis presented above reveals that factors such as income, human capital, telecommunications, rule of law, and banking sector development may contribute to the global digital divide. The analysis, however, does not identify the relative importance of these factors in contributing to the alarming differences between developing countries and developed countries. Explanations for low technology penetration rates may also differ across individual developing countries.

To explore these issues further we borrow from a technique of decomposing inter-group differences in a dependent variable into those due to different observable characteristics across groups and those due to different "prices" of characteristics of groups (see Blinder 1973 and Oaxaca 1973). The technique has been widely used to decompose earnings gaps between whites and blacks or men and women using microdata. The Blinder-Oaxaca technique, however, can be used to decompose a gap between any two groups or even countries. In particular, the difference between an outcome, $Y$, for group $i$ and $j$ can be expressed as:

$$
\bar{Y}^{i}-\bar{Y}^{j}=\left(\bar{X}^{i}-\bar{X}^{j}\right) \hat{\beta}^{i}+\bar{X}^{j}\left(\hat{\beta}^{i}-\hat{\beta}^{j}\right),
$$

where $\bar{X}^{i}$ is a row vector of average values for the individual-level characteristics and $\hat{\beta}^{i}$ is a vector of coefficient estimates for group $i$. The first term in the decomposition represents the part of the gap that is due to group differences in average values of the independent variables, and the second term represents the part due to differences in the group processes determining the outcome, which is often referred to as the "unexplained" component. The first term can be further decomposed into the separate contributions from group differences in specific variables and is the focus of the following analysis.

The technique is commonly modified to use coefficients from a pooled sample of both

groups, $\hat{\beta}$, to weight the first expression in the decomposition (see Oaxaca and Ransom 1994 for example). We adopt this approach to calculate the decompositions. In particular, we use coefficient estimates from regressions that include all countries in our sample (reported in column 2 of tables 2 and 3). We then denote the average for all developed countries as the base or reference group and calculate the decomposition for computer and Internet penetration rate gaps between the developed country average and several large developing countries. Thus, the 
first term in the decomposition that captures the explained variation in penetration rates between the developed world and developing country $j$ is:

$$
\left(\bar{X}^{D d}-\bar{X}^{j}\right) \hat{\beta}
$$

where $\hat{\beta}$ are the coefficients and $\bar{X}$ represents the three-year average of the independent variables included in the regressions. The technique allows us to quantify the separate contributions from differences in income, human capital, telephones, and other factors, to the gaps in computer and Internet penetration rates between the developed country average and developing country $j$.

\subsection{Computer Use Contributions}

Table 5 reports the results for contributions to the gaps in computer penetration rates between the average for developed countries and several of the largest developing countries and an average for all developing countries. The decomposition is performed for the four largest developing countries -- China, India, Indonesia and Brazil. We also report decomposition estimates for Nigeria and Mexico which are the $7^{\text {th }}$ and $8^{\text {th }}$ largest developing countries, respectively. All developing countries have substantially lower computer penetration rates than the developed country average. The computer penetration rate is 50.5 percent for developed countries.

The largest single factor contributing to the disparities in computer penetration rates is per capita income. Income differences explain 43.7 percentage points of the gap between developed and developing countries. The large contributions to the computer penetration rate gaps are not surprising considering the enormous disparities in income levels between developed and developing countries. The average per capita income (PPP adjusted) in developed countries is $\$ 30,108$ compared to $\$ 4,085$ in developing countries. The income gap is likely affecting computer penetration by way of the cost relative to income. A personal computer costing $\$ 1000$ represents one fourth of a person's average annual income in developing countries. Interestingly, the explanatory power of income differs somewhat across countries. For example, income differences explain 35.1 percentage points of the computer penetration rate gap for Mexico whereas these differences explain 50.7 percentage points of the gap for Nigeria.

Another important factor in contributing to the computer penetration rate gaps is per capita telephone lines. This factor explains 16.1 percentage points of the overall gap between developed and developing countries, and from 11.7 to 22.2 percentage points of the gaps for 
specific countries. These results suggest that the assertion that the global digital divide is just a manifestation of a long-standing disparity in telecommunications access appears to be partly true (Dasgupta, et al. 2001). Interestingly, however, the effects of differences in telecommunications infrastructure are not due to costs, at least as measured by monthly subscription and per minute telephone charges. The contributions from these factors are essentially zero for all countries.

Human capital disparities, as measured by years of schooling, contribute to the divide between developed and developing countries. Differences in education explain 6.1 percentage points of the total developed/developing country gap and from 3.7 to 6.7 percentage points of the individual country gaps even after controlling for differences in income. Computers require some education for use, limiting demand in countries with relatively low levels of human capital. Hence, we confirm the findings of Caselli and Coleman (2001) and Pohjola (2003).

Developing countries generally have younger populations than developed countries, a factor which provides a negative contribution to the computer penetration rate gaps. In other words, the computer penetration rate gaps would be even larger if developing countries had older populations more similar to the developed world. In particular, a larger percent of the population in developing countries is between the ages of 0-14, which leads to higher demand for computers, all else equal.

Most other factors provide small contributions to the gaps in computer penetration rates between developed and developing countries. This finding is consistent with the relatively small and statistically insignificant coefficients on these variables in the regression models. One exception is that the point estimate, although insignificant, on rule of law and large differences in average values for this measure lead to a positive contribution of roughly 5 percentage points. The imprecision of the coefficient estimate and lack of robustness across alternative specifications reported in Table 2 provide some uncertainty regarding the importance of this factor.

\subsection{Internet Decomposition Results}

Table 6 reports the results for contributions to gaps in Internet penetration rates between developed and developing countries. The Internet rate is 47.4 percent in developed countries compared to 4.8 percent in developing countries resulting in a 42.7 percentage point gap. Similar to the results for the computer penetration rate gaps, income differences are the most 
important factor. For differences in Internet penetration, however, the explanatory power is somewhat smaller. For example, income differences explain 20.6 percentage points of the gap in Internet penetration between developed and developing countries. This finding is consistent with the cost of Internet access being substantially lower than the cost of purchasing a personal computer and the prevalence of Internet cafes providing inexpensive access in some developing countries (Wallsten 2004, 2005).

The second most important factor contributing to differences in Internet penetration rates is rule of law. Overall, differences between developed and developing countries in this measure explain nearly 10 percentage points of the Internet penetration rate gap. The quality of legal institutions may represent an important barrier to increasing Internet penetration in developing countries. This appears to be especially likely in Nigeria where 16.1 percentage points of the Internet penetration rate gap is explained by lower quality legal institutions than in the developed world. For comparison, income differences explain 24.3 percent of the gap for Nigeria.

Differences in the development of the banking sector explain part of the gaps in Internet penetration rates. For all developing countries, this factor explains 6.3 percentage points of the Internet gap. The contribution estimates for large developing countries do not vary substantially, contributing 6.0 to 7.2 percentage points to the gaps. Restricted access to credit provided by the banking sector may limit investment in IT equipment in many developing countries.

The decomposition estimates indicate positive contributions from differences in access to telephones, electricity and human capital, but the original coefficient estimates are statistically insignificant limiting the confidence placed on these estimates. In no cases, however, are these contributions large even with imprecisely measured coefficients. The contribution estimates from the telephone cost variables are very small. Similar to the results presented above, the relative youth of developing countries mitigates the extent of the digital divide.

\section{The Dynamics of ICT Diffusion and Adoption}

\subsection{Modeling Issues}

Estimates from the 2002-2004 panel regressions shed light on the determinants of current disparities in computer and Internet penetration for developing countries, but do not highlight the dynamics associated with the diffusion and adoption of new information and communication technologies over time. As noted above, computer and Internet penetration rates among 
developing countries have risen dramatically over the past several years. To examine this issue more closely, we appeal to the large literature on technology adoption. Many models of technology adoption incorporate a type "S" shaped curve of use; early references include Stoneman's early (1976) study of computer use. As Geroski (2000) observes, there are many different types of theoretical models that are reconcilable with such patterns, ranging from exotic ones such as epidemic models and information cascades, to more prosaic partial adjustment models.

We choose to use a Gompertz model, which implies an asymmetric "S" time-path for technology penetration. This specification was also adopted by Kiiski and Pohjola (2002) in their examination of the diffusion of the Internet, although we apply this to a broader set of countries over a more recent period, and use a different measure of technology diffusion.

Let $y$ denote the log value of the variable of interest, and $\tilde{y}_{i}$ be the post-diffusion or equilibrium level of penetration.

$$
y_{i t}-y_{i t-k}=\varphi_{1}\left(\tilde{y}_{i}-y_{i t-k}\right)
$$

this specification has the flavor of an error correction model (ECM) commonly used in time series analysis. However, one key difference is that $\tilde{y}_{i}$ is the current equilibrium, rather than the lagged, as would be the case in a conventional ECM. Assuming the equilibrium is time-invariant would make the two specifications identical. Then $\varphi_{1}$ has the interpretation of being the rate of reversion to equilibrium.

We allow for time variation in the equilibrium value of $y$. Letting $X_{i t}$ denote the determinants of $\tilde{y}_{i t}$ leads the following specification:

$$
y_{i t}-y_{i t-k}=-\varphi_{1} y_{i t-k}+X_{i t} B
$$

\subsection{Empirical Implementation}

We undertake these dynamic regressions using the same set of explanatory variables as those discussed in Section 5. In principle, the lag length and the horizon over which the growth rate is calculated can take on any value. However, because there is so much noise in year to year changes, we undertake some averaging by way of examining the average growth rate over five years (hence the coefficients on the lagged log technology penetration ratios can be taken as the annual rate of reversion). 
The results for computer and Internet penetration are presented in Table 7. For all computer specifications, the reversion coefficients uniformly show up as statistically significant. The half life of a deviation from the long run equilibrium ranges between 11 and 17 years. It is important to understand that this does not mean that the gap between current levels of PC use and PC use in the country will disappear in 11-17 years; rather half the gap between the current levels of computer use and the long run equilibrium level of use implied by current per capita income, current telephone density, etc., is eliminated in this period, on average. Since the right hand side variables are also moving over time, the actual time taken to close half the gap may be longer.

In column 1, the pricing variables enter in significantly, with the price of a three minute call negatively related to computer penetration. On the other hand, the subscription price has a positive effect, although this result might be rationalized by the fact that high prices are correlated with good telephone service (in terms of connectivity). Dropping the telephone pricing and electricity variables, in column 2, does not substantially change the nature of the results, with the exception of the coefficient on the bank lending variable. This statistically significant result indicates that higher levels of private credit to GDP lead to a higher equilibrium computer penetration rate. The different result probably arises from the expanded sample (about 30\% larger). If a stock market variable is substituted for the bank lending variable, the sample size drops while the qualitative nature of the estimates on the other coefficients is unchanged.

For the Internet penetration regressions (columns 4-6), the results are clearer. In all instances, the rate of reversion to equilibrium is again statistically significant; indeed the rate of diffusion is even more rapid than in the case of computers. Half of the gap between the current level of internet penetration and the equilibrium is eliminated in between seven to eight years.

The number of telephone main lines is statistically significant across specifications, although - interestingly - the pricing variables do not exhibit significance, just as they failed to evidence importance in the static regressions. Generally, there are few statistically significant coefficients, but this is likely a result of the relatively small sample size.

Once the telephone pricing and electricity variables are dropped from the regression, the sample size increases by about a third. The estimated rate of reversion is slightly higher, and while no other coefficients are statistically significant at conventional levels, trade openness and financial openness are significant, with the expected sign, at the $15 \%$ and $12 \%$ levels. Finally, 
substituting the stock market measure of financial development for the bank lending measure leaves the other coefficients largely unchanged, ${ }^{13}$ while financial development now enters with a high level of statistical significance.

Given the apparent heterogeneity of behavior across developing and other countries, it seems appropriate to stratify the sample by country type. These estimates are reported in Table 8 . In column 1, the PC penetration dynamics for developing countries are displayed. While the coefficient estimate indicates reversion to equilibrium, it is imprecisely estimated. Conditional on convergence to a long run equilibrium, telephone pricing effects are as estimated in the full sample, while demographics also show up as more important than before. Per capita income also enters in with a positive coefficient.

In contrast, computer penetration rates in other countries (largely developed economies) do not appear to be converging, although the estimated reversion rate in column 2 is not statistically significant. Given the relatively limited variability in this smaller more homogeneous sample, this outcome is not too surprising. Dropping the telephone pricing and electricity consumption variables does not alter this pattern.

For the Internet, both sets of countries exhibit rapid rates of reversion to long run equilibrium. Main telephone lines also matter in developing countries (columns 4 and 5), but pricing variables do not. Financial development as measured by bank lending is not significantly linked to Internet penetration, while the stock market variable is. For other countries, telephone line density has no statistical impact, and indeed, almost no variable has a statistically detectable effect. We also find in these regressions that openness - either trade or financial - does seem to matter in a positive way for Internet adoption in developing countries. Trade openness and financial openness always have positive, albeit insignificant, coefficients.

It is not straightforward to compare our dynamic results to estimates from previous research using earlier data with much lower technology penetration rates. In their study of Internet hosts per capita, Kiiski and Pohjola (2002) find a similar rate of reversion for the OECD countries over the 1995-2000 period, while obtaining a larger estimate for per capita income; however, they omit institutional factors that might be correlated with per capita income.

\footnotetext{
${ }^{13}$ The GNI per capita variable now enters with a statistically significant negative sign; this result only occurs with the smaller sample, and we conjecture it arises because of the multicollinearity between lagged log Internet penetration ratio and the log per capita income level (the two are correlated with a coefficient of about 0.80 ).
} 
Interestingly, they also conclude that the average years of schooling variable does not enter in significantly, even if the sign of the estimated coefficient is correct.

Note that in many cases the static regressions yield levels of statistical significance for certain coefficients different from those obtained in these dynamic regressions (although the signs of the coefficients typically agree). In particular, there are much fewer instances of statistical significance in the dynamic regressions; this indicates to us that it is hard to precisely identify the long run parameters. On the other hand, given the high level of statistical significance for the estimated reversion coefficients, the dynamic regressions clearly indicate that some countries are away from their long run levels of technology penetration. Estimation of the dynamic equations provides insights into the trajectory of these economies over time.

\section{Conclusions}

In this study focusing on differences between developed and developing countries, we obtain a series of results that are likely to be useful for informing the discussion about the sources of the global digital divide, and the importance of various determinants of that divide. First, as in earlier work, we confirm the importance of per capita income in explaining the gap in computer and Internet use. This factor remains the single largest factor in our static regressions. Second, we find that in a broad sample encompassing developed and developing countries, telephone access pricing variables that have garnered attention do not exhibit statistical or economic importance in explaining the Internet gap. This result should not be construed as implying that pricing policies are not important, but rather that such factors are minor by comparison to economic, demographic and institutional factors in heterogeneous samples.

Third, the level of legal development is important. Differences in legal development as measured by the Rule of Law index sometimes account for substantial portions of the gaps in technology use. For instance, 19 percent of the Nigeria/Developed Country Internet gap is associated with the difference in legal development. More generally, our estimates suggest that over one-tenth of the aggregate Internet penetration rate gap might be closed if less developed countries had similar legal development as the average level in developed economies. To place this result in context, this effect is comparable to that flowing from differences in educational attainment. 
Finally, in our dynamic regressions we find that the evidence for reversion to long run equilibrium is pronounced for both technologies when the entire sample is taken into account. The evidence in favor of reversion is more muted for PC penetration when examining a fairly small and homogenous sample of developed economies. On the other hand, in casting the net wider to encompass a diverse set of developing countries, reversion to equilibrium in Internet use is readily detectable. Moreover, we find that the gaps between current and equilibrium levels of technology penetration are shrinking faster for Internet use than for PC use. However, our modeling results are consistent with the conclusion that even if developing and developed countries were at their long run equilibrium levels of technology penetration, gaps would still remain between penetration rates in the two groups because the determinants (per capita income, openness) differ. In other words, economic growth alone is insufficient to close the global digital divide.

\section{Acknowledgements}

We thank Thomas Wu for helpful comments, Tanapong Potipiti for assistance in collecting and compiling data, and Hiro Ito for providing data. Financial support of UW and UCSC faculty research funds, and a grant from the NET Institute, is gratefully acknowledged. 


\section{References}

Beck, T., Demirgüc-Kunt. A., and Levine, R. (2000). A new database on financial development and structure, Policy Research Paper No. 2147 (Washington, D.C.: World Bank).

Brynjolfsson, E., and Hitt, L. (2003) Computing productivity: Firm-level evidence, Review of Economics and Statistics, 85, 793-808.

Casseli, F., and Coleman, W.J., II (2001) Cross-country technology diffusion: The case of computers, American Economic Review, 91, 328-335.

Chinn, M.D. and Fairlie, R.W. (2006), "The Determinants of the Global Digital Divide: A CrossCountry Analysis of Computer and Internet Penetration," forthcoming, Oxford Economic Papers.

Chinn, M.D., and Ito, H. (forthcoming) What Matters for Financial Development? Capital Controls, Institutions and Interactions, Journal of Development Economics.

Chong, A., and Micco, A. (2003) The Internet and the ability to innovate in Latin America, Emerging Markets Review, 4, 53-72.

Comin, D., Hobijn, B., and Rovito, E. (2006) Five Facts You Need to Know About Technology Diffusion, NBER Working Paper No. 11928 (January).

Council of Economic Advisers (2001) Economic Report of the President, 2001, U.S.

Government Printing Office, Washington, D.C.

Dasgupta, S., Lall, S., and Wheeler, D. (2001) Policy reform, economic growth and the digital divide: An econometric analysis, Working Paper No. 2567 (World Bank).

Dedrick, J., Gurbaxani, V., and Kraemer, K. (2003) Information technology and economic performance: A critical review of the empirical evidence, ACM Computing Surveys, 35, 1-28.

Estache, A., Manacorda, M. and Valletti, T.M. (2002) Telecommunication reforms, access regulation and Internet adoption in Latin America, Economía, 2, 153-217

Fairlie, R.W. (2004) Race and the Digital Divide, Contributions to Economic Analysis \& Policy, The B.E. Journals, 3, Article 15, 1-38.

Fink, C. and Kenny, C. (2003) W(h)ither the digital divide? Info, The journal of policy, regulation and strategy for telecommunications, 5, 15-24.

Hargittai, E. (1999) Weaving the Western Web: Explaining differences in Internet connectivity among OECD Countries, Telecommunications Policy, 23, 701-718. 
Kaufmann, D., Kraay, A., and Mastruzzi, M. (2003) Governance matters III: Governance indicators for 1996-2002, Development and Comp Systems 0308001, Economics Working Paper Archive at WUSTL.

Kawaguchi, D. (2005) Are computers at home a form of consumption or investment? A longitudinal analysis for Japan, Japanese Economic Review, forthcoming.

Kiiski, S., and Pohjola, M. (2002) Cross-country diffusion of the Internet, Information Economics and Policy, 14, 297-310.

Liu, M.-C., and San, G., undated, Social conditions and the digital divide: Examining the role of Internet diffusion, mimeo, Chung-Hua Institution for Economic Research.

Mann, C., Eckert, S.E., and Knight, S.C. (2000) Global Electronic Commerce: A Policy Primer, Institute for International Economics, Washington, D.C.

Norris, P. (2001) Digital Divide: Civic Engagement, Information Poverty, and the Internet Worldwide, Cambridge University Press, Cambridge, U.K.

OECD (2006) ICTs and Economic Growth in Developing Countries, Development Assistance Committee of the Organization for Economic Cooperation and Development, Paris.

OECD (2001) Understanding the Digital Divide, Organization for Economic Cooperation and Development, Paris.

Ono, H., and Zavodny, M. (2005) "Digital Inequality: A Five Country Comparison Using Microdata," Paper prepared for the American Sociological Association Meeting, Philadelphia, August 2005.

Ono, H., and Zavodny, M. (2004) Gender differences in information technology usage: A U.S.Japan comparison, Working Paper No. 2004-2, Federal Reserve Bank of Atlanta.

Oshikoya, T.W., and Husseain, M. N. (1998) Information technology and the challenge of economic development in Africa, Economic Research Papers No. 36, African Development Bank, Abidjian, Côte d'Ivoire.

Oyelaran-Oyeyinka, B. and Lal, K. (2003) The Internet diffusion in Sub-Saharan Africa: A cross-country analysis, Institute for New Technologies Discussion Paper No. 2003-5, UN University, Helsinki.

Pohjola, M. (2003) The adoption and diffusion of ICT across countries: Patterns and determinants, The New Economy Handbook, Academic Press, New York.

Primrose, J. (2003) 2001 Census: Computer and Internet use, Census Paper No. 03/03, Australian Bureau of Statistics. 
Quibria, M. G., Ahmed, S.N., Tschang, T., and Reyes-Macasaquit, M.-L. (2003) Digital divide: Determinants and policies with special reference to Asia, Journal of Asian Economics, 13, 811825.

Sinai, T., and Waldfogel, J. (2004) Geography and the Internet: Is the Internet a substitute or a complement for cities? Journal of Urban Economics, 56, 1-24.

Singh, V. (2004) Factors associated with household Internet use in Canada, 1998-2000, Rural and Small Town Canada Analysis Bulletin, Statistics Canada, Catalogue no. 21-006-XIE, 5.

Steinmuller, W. E. (2001) ICTs and the possibilities of leapfrogging by developing countries, International Labour Review, 140, 193-210.

U.S. Department of Commerce (2000) Falling Through the Net: Toward Digital Inclusion, U.S. Government Printing Office, Washington, D.C.

U.S. Department of Commerce (2002) A Nation Online: How Americans are Expanding Their Use of the Internet, U.S. Government Printing Office, Washington, D.C.

Wallsten, Scott. (2004) "Internet Service in India," Internet Policy in India, eds. Roger Noll and Scott Wallsten.

Wallsten, Scott. (2005) Regulation and Internet use in developing countries, Economic Development and Cultural Change, 53, 501-23.

World Bank (2003) World Development Indicators, World Bank, Washington, DC. Available at: http://www.worldbank.org/data/wdi2002/index.htm 


\section{Appendix \\ Variable Descriptions and Sources}

Key:

ITU: International Telecommunications Union, World Telecommunication Indicators Database. WDI: World Bank, World Development Indicators.

ES: World Bank, EdStats.

BDL: Beck, Demirgüc-Kunt, and Levine (2000).

KKM: Kaufman, Kraay and Mastruzzi (2003).

Personal computers per 100 people: Estimates are derived from annual questionnaires supplemented by other sources. Source: ITU.

Internet users per 100 people: The number of Internet users is based on reported estimates, derivations based on reported Internet Access Provider (ISP) subscriber counts, or calculated by multiplying the number of hosts by an estimated multiplier. Source: ITU.

Main telephone lines per 100 people: Main telephone lines refer to telephone lines connecting a customer's equipment (e.g. telephone set, facsimile machine) to the Public Switched Telephone Network (PSTN) and which have a dedicated port on a telephone exchange. For most countries, main lines also include public payphones. Source: ITU.

Monthly telephone subscription charge: The monthly telephone subscription charge is the average of the residential and business subscription charges and is converted to international dollars using purchasing power parity rates provided by the World Bank. Monthly subscription refers to the recurring fixed charge for subscribing to the Public Switched Telephone Network. The charge covers the rental of the line but not the rental of the terminal (e.g., telephone set) where the terminal equipment market is liberalized. Source: ITU, WDI, and authors' calculations.

Cost of three minute local call: The cost of a three minute local call during peak rates is converted to international dollars using purchasing power parity rates provided by the World Bank. Source: ITU, WDI, and authors' calculations.

Electric power consumption (kwh per capita): Source: WDI.

Population ages 0-14 (\% of total): Source: WDI.

Population ages 65 and above (\% of total): Source: WDI.

Urban population (\% of total): Source: WDI.

Gross national income per capita: Gross national income is converted to international dollars using purchasing power parity rates provided by the World Bank. An international dollar has the same purchasing power over GNI as a U.S. dollar has in the United States. Source: WDI. 
Trade in goods (\% of GDP): Sum of exports and imports, divided by GDP. Source: WDI.

Years of schooling: Average years of schooling of adults. Source: ES.

Rule of Law: A composite index that includes several indicators which measure the extent to which agents have confidence in and abide by the rules of society. These include perceptions of the incidence of crime, the effectiveness and predictability of the judiciary, and the enforceability of contracts. An Unobserved Component Model (UCM) is used to aggregate the various responses in the broad 6 clusters where the weights are proportional to the reliability of each source. The resulting estimates of governance have an expected value (across countries) of zero, and a standard deviation (across countries) of one. Source: KKM.

Regulatory quality: The regulatory quality index focuses specifically on the policies, including measures of the incidence of market-unfriendly policies such as price controls or inadequate bank supervision, as well as perceptions of the burdens imposed by excessive regulation in areas such as foreign trade and business development. Source: KKM.

Bank based measure of financial development: Ratio of private credit by deposit money banks to GDP. Source: BDL, 1970 - 97, updated by Hiro Ito, using data from WDI and IMF, International Financial Statistics.

Stock market based measure of financial development: Ratio of equity market total value traded to GDP. Alternative measures of stock market based measures: (i) Ratio of equity market capitalization ratio to GDP, and (ii) Equity market turn over ratio. Source: BDL, 1975-97, updated by Hiro Ito, using data from WDI and IMF, International Financial Statistics. 
Figure 1

Computer Penetration Rates by Country Type (ITU 1995-2004)

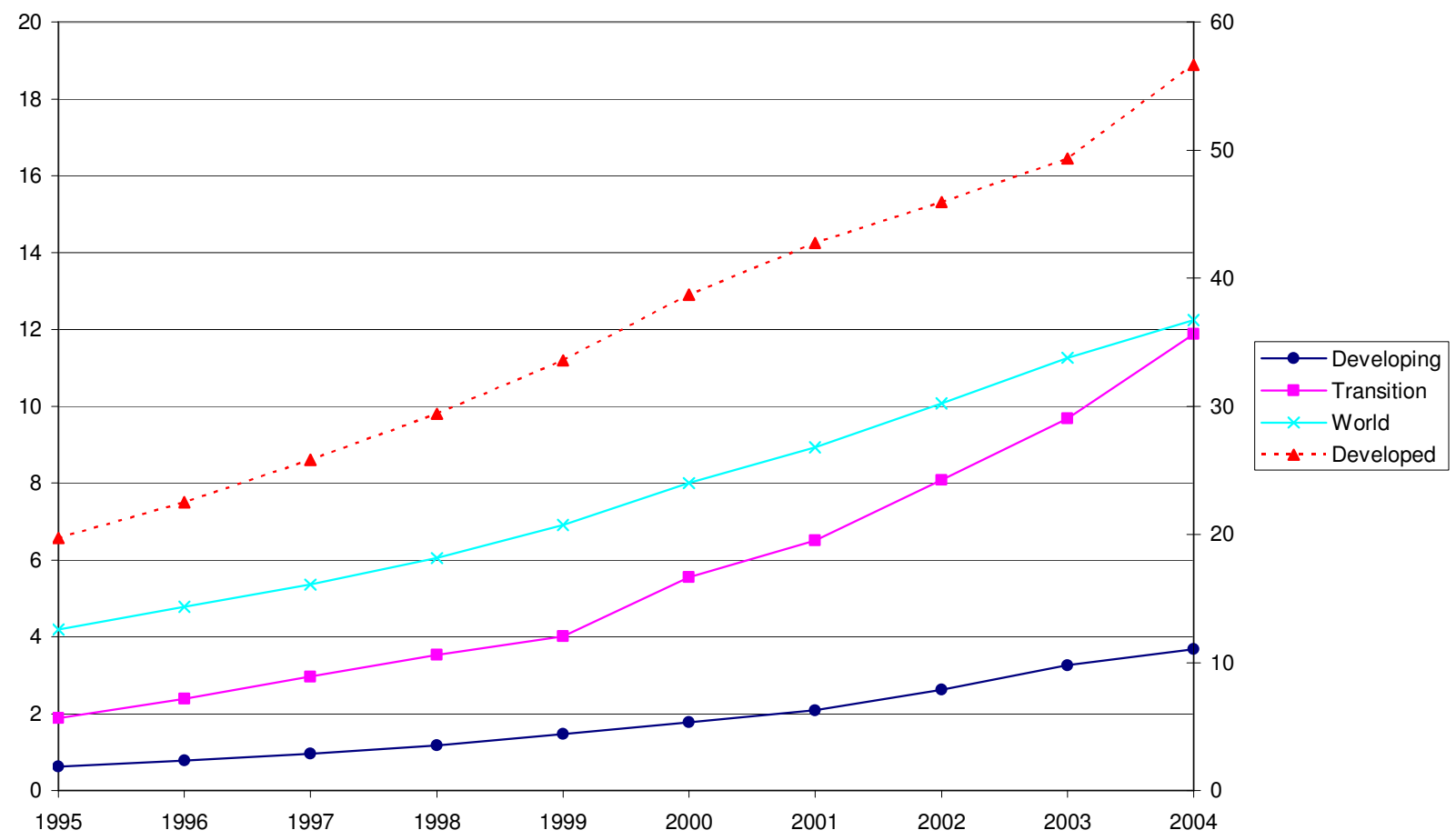


Figure 2

Internet Penetration Rates by Country Type (ITU 1995-2004)

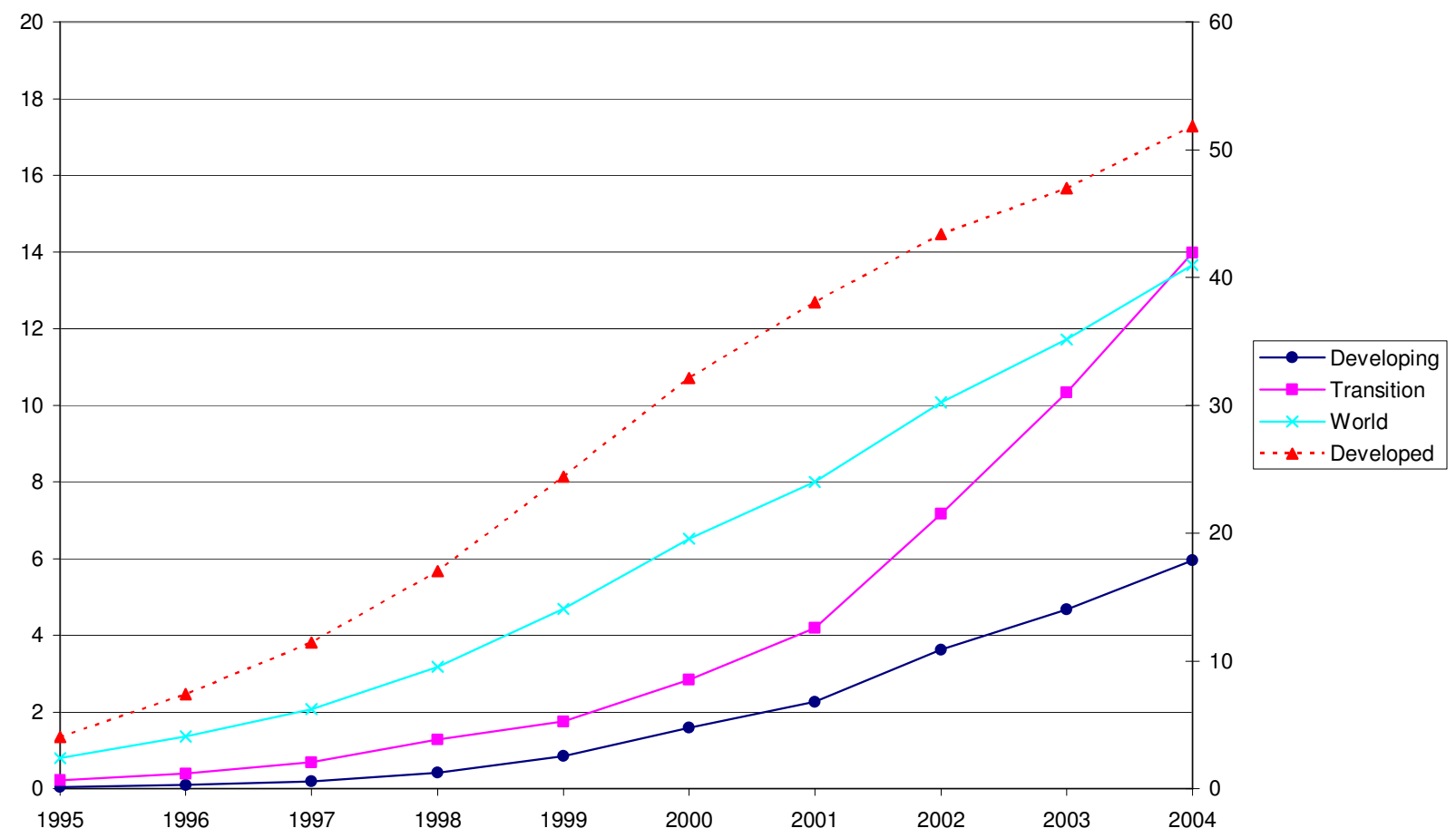


Figure 3

Computer Penetration Rates, ITU (1999-2004)

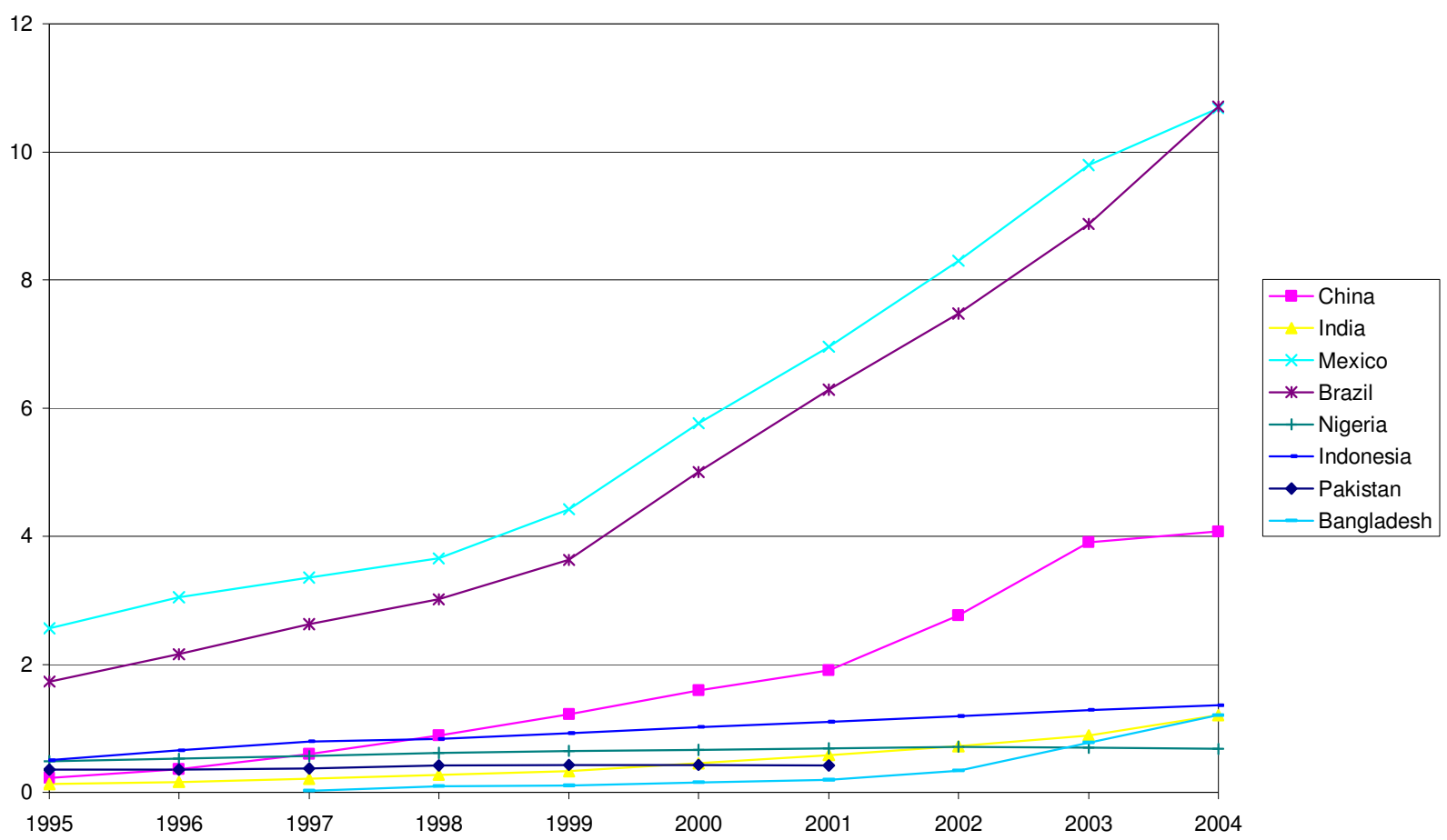


Figure 4

Internet Penetration Rates, ITU (1999-2004)

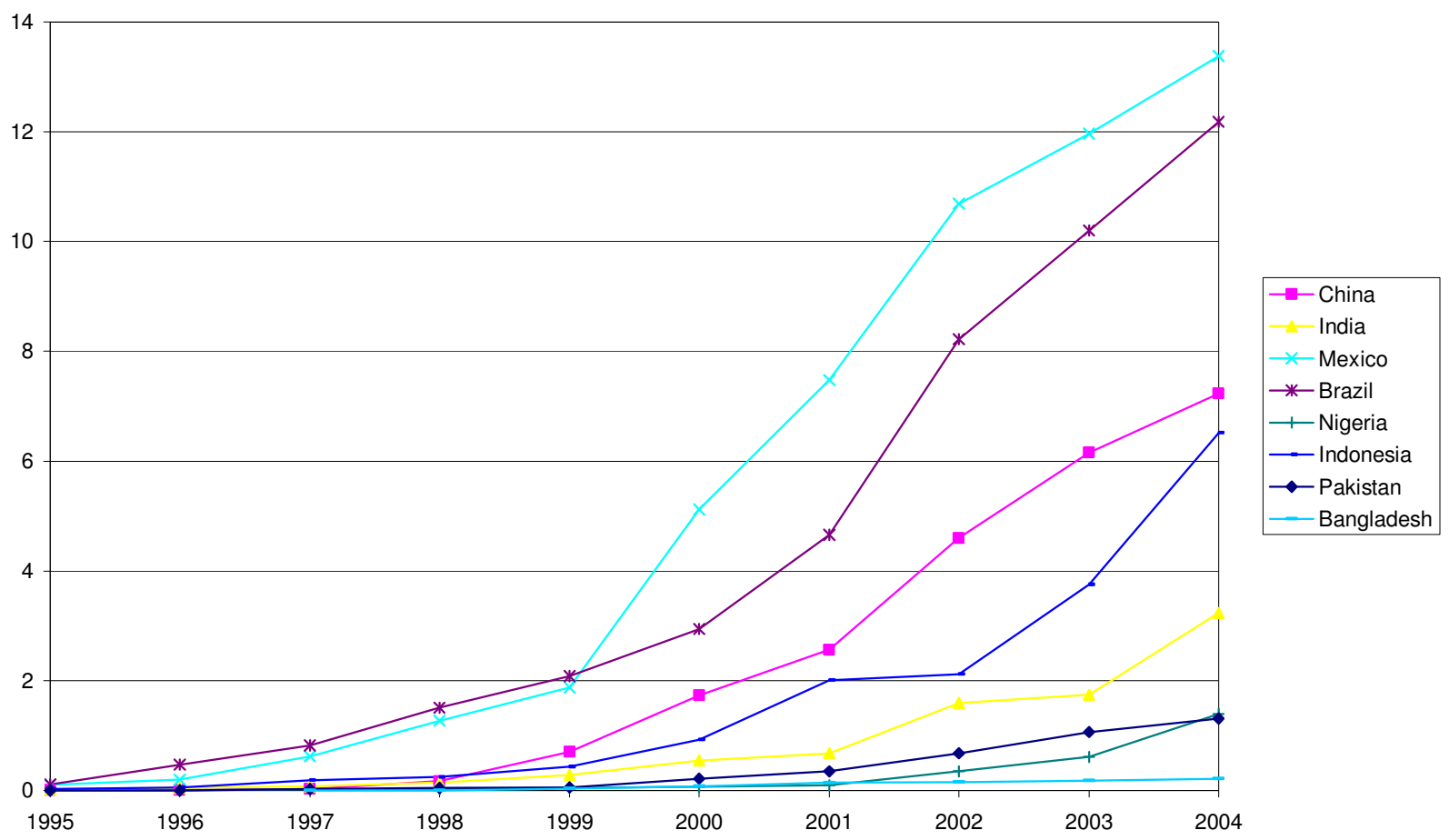


Table 1

Computer and Internet Penetration Rates

International Telecommunications Union (2004)

\begin{tabular}{|c|c|c|c|}
\hline Country & $\begin{array}{c}\text { Computers } \\
\text { per } 100\end{array}$ & $\begin{array}{c}\text { Internet Users } \\
\text { per } 100\end{array}$ & $\begin{array}{c}\text { Population } \\
\text { (000s) }\end{array}$ \\
\hline World & 12.24 & 13.65 & $6,359,891$ \\
\hline Developed Countries & 56.64 & 51.83 & 983,477 \\
\hline Transition Countries & 11.89 & 13.98 & 403,681 \\
\hline Developing Countries & 3.68 & 5.95 & $4,972,734$ \\
\hline \multicolumn{4}{|l|}{ Largest Developing Countries } \\
\hline China & 4.08 & 7.23 & $1,300,000$ \\
\hline India & 1.21 & 3.24 & $1,081,000$ \\
\hline Indonesia & 1.36 & 6.52 & 222,600 \\
\hline Brazil & 10.71 & 12.18 & 180,700 \\
\hline Pakistan & & 1.31 & 152,500 \\
\hline Bangladesh & 1.20 & 0.22 & 137,100 \\
\hline Nigeria & 0.68 & 1.39 & 127,100 \\
\hline Mexico & 10.68 & 13.38 & 104,900 \\
\hline Philippines & 4.46 & 5.32 & 82,652 \\
\hline Viet Nam & 1.27 & 7.12 & 82,481 \\
\hline Ethiopia & 0.31 & 0.16 & 72,420 \\
\hline Turkey & 5.12 & 14.13 & 72,320 \\
\hline Egypt & 3.29 & 5.57 & 69,997 \\
\hline Iran (Islamic Rep. of) & 10.53 & 7.88 & 69,789 \\
\hline Thailand & 6.00 & 11.25 & 61,974 \\
\hline Congo (Democratic Republic of the) & & & 54,417 \\
\hline Myanmar & 0.60 & 0.12 & 54,000 \\
\hline Colombia & 5.53 & 8.94 & 45,325 \\
\hline South Africa & 8.27 & 7.89 & 45,214 \\
\hline Argentina & & 16.10 & 38,226 \\
\hline Tanzania & 0.74 & 0.88 & 37,671 \\
\hline Sudan & 1.76 & 3.30 & 34,512 \\
\hline Kenya & 1.36 & 4.63 & 32,420 \\
\hline Algeria & 0.90 & 2.61 & 32,339 \\
\hline Morocco & 2.07 & 11.71 & 29,900 \\
\hline Peru & 9.69 & 11.61 & 27,746 \\
\hline Uganda & 0.45 & 0.75 & 26,699 \\
\hline Venezuela & 8.19 & 8.84 & 26,175 \\
\hline Iraq & & 0.14 & 25,856 \\
\hline Malaysia & 19.16 & 38.62 & 25,580 \\
\hline
\end{tabular}


Table 2

Computer Penetration Rate Regressions (2002-2004)

\begin{tabular}{|c|c|c|c|c|c|}
\hline Explanatory Variables & $(1)$ & $(2)$ & $\begin{array}{l}\text { pecification } \\
\text { (3) }\end{array}$ & $(4)$ & (5) \\
\hline $\begin{array}{l}\text { Main telephone lines per } \\
100 \text { people }\end{array}$ & $\begin{array}{c}0.3141 \\
(0.1164)\end{array}$ & $\begin{array}{c}0.3608 \\
(0.1276)\end{array}$ & $\begin{array}{c}0.2894 \\
(0.1333)\end{array}$ & $\begin{array}{c}0.2942 \\
(0.1073)\end{array}$ & $\begin{array}{c}0.2762 \\
(0.0955)\end{array}$ \\
\hline $\begin{array}{l}\text { Monthly telephone } \\
\text { subscription charge }\end{array}$ & $\begin{array}{l}-0.0189 \\
(0.0655)\end{array}$ & $\begin{array}{l}-0.0168 \\
(0.0685)\end{array}$ & $\begin{array}{l}-0.0640 \\
(0.0818)\end{array}$ & & \\
\hline $\begin{array}{l}\text { Cost of three minute local } \\
\text { call }\end{array}$ & $\begin{array}{l}-4.8559 \\
(3.8358)\end{array}$ & $\begin{array}{l}-4.8667 \\
(4.1236)\end{array}$ & $\begin{array}{l}-7.0884 \\
(4.6178)\end{array}$ & & \\
\hline $\begin{array}{l}\text { Electric power consumption } \\
\quad \text { (kwh per capita) }\end{array}$ & $\begin{array}{l}-0.0007 \\
(0.0011)\end{array}$ & $\begin{array}{l}-0.0009 \\
(0.0013)\end{array}$ & $\begin{array}{l}-0.0006 \\
(0.0013)\end{array}$ & & \\
\hline $\begin{array}{l}\text { Population ages } 0-14 \\
\text { (\% of total) }\end{array}$ & $\begin{array}{c}0.6360 \\
(0.2333)\end{array}$ & $\begin{array}{c}0.6507 \\
(0.2569)\end{array}$ & $\begin{array}{c}0.5148 \\
(0.2691)\end{array}$ & $\begin{array}{c}0.5507 \\
(0.1937)\end{array}$ & $\begin{array}{c}0.2731 \\
(0.1756)\end{array}$ \\
\hline $\begin{array}{l}\text { Population ages } 65 \text { and } \\
\text { above (\% of total) }\end{array}$ & $\begin{array}{l}-0.6412 \\
(0.4432)\end{array}$ & $\begin{array}{l}-0.8679 \\
(0.5126)\end{array}$ & $\begin{array}{l}-0.9740 \\
(0.5115)\end{array}$ & $\begin{array}{l}-0.7563 \\
(0.4134)\end{array}$ & $\begin{array}{l}-0.6100 \\
(0.3744)\end{array}$ \\
\hline Urban population (\% of total) & $\begin{array}{l}-0.0933 \\
(0.0596)\end{array}$ & $\begin{array}{l}-0.0567 \\
(0.0676)\end{array}$ & $\begin{array}{l}-0.0452 \\
(0.0643)\end{array}$ & $\begin{array}{l}-0.0205 \\
(0.0509)\end{array}$ & $\begin{array}{l}-0.0190 \\
(0.0430)\end{array}$ \\
\hline $\begin{array}{l}\text { Gross national income per } \\
\text { capita (000s) }\end{array}$ & $\begin{array}{c}1.6948 \\
(0.2649)\end{array}$ & $\begin{array}{c}1.6803 \\
(0.2959)\end{array}$ & $\begin{array}{c}1.5682 \\
(0.3009)\end{array}$ & $\begin{array}{c}1.7328 \\
(0.2230)\end{array}$ & $\begin{array}{c}1.7124 \\
(0.1964)\end{array}$ \\
\hline Years of schooling & $\begin{array}{l}1.4555 \\
(0.6430)\end{array}$ & $\begin{array}{l}1.2997 \\
(0.7075)\end{array}$ & $\begin{array}{l}1.7843 \\
(0.7671)\end{array}$ & $\begin{array}{c}0.7466 \\
(0.5609)\end{array}$ & \\
\hline Rule of law & $\begin{array}{l}2.0991 \\
(2.0201)\end{array}$ & $\begin{array}{l}2.8534 \\
(2.3442)\end{array}$ & $\begin{array}{l}2.6947 \\
(2.3140)\end{array}$ & $\begin{array}{c}0.2115 \\
(1.8815)\end{array}$ & $\begin{array}{l}-0.7675 \\
(1.5066)\end{array}$ \\
\hline Trade in goods ( $\%$ of GDP) & $\begin{array}{c}0.0273 \\
(0.0186)\end{array}$ & $\begin{array}{c}0.0190 \\
(0.0248)\end{array}$ & $\begin{array}{c}0.0131 \\
(0.0252)\end{array}$ & $\begin{array}{c}0.0121 \\
(0.0195)\end{array}$ & $\begin{array}{c}0.0149 \\
(0.0179)\end{array}$ \\
\hline Financial openness & & $\begin{array}{l}-0.0900 \\
(0.6749)\end{array}$ & $\begin{array}{l}-0.2159 \\
(0.7357)\end{array}$ & $\begin{array}{c}0.0381 \\
(0.5324)\end{array}$ & $\begin{array}{c}0.0273 \\
(0.4728)\end{array}$ \\
\hline $\begin{array}{l}\text { Private credit by banks and } \\
\text { oth. fin. insts. / GDP }\end{array}$ & & $\begin{array}{c}0.3457 \\
(3.1363)\end{array}$ & & $\begin{array}{c}2.4619 \\
(2.8051)\end{array}$ & $\begin{array}{c}1.9805 \\
(2.6362)\end{array}$ \\
\hline $\begin{array}{l}\text { Stock market total value } \\
\text { traded / GDP }\end{array}$ & & & $\begin{array}{l}3.3105 \\
(2.0922)\end{array}$ & & \\
\hline Illiteracy rate & & & & & $\begin{array}{c}0.0020 \\
(0.0531)\end{array}$ \\
\hline $\begin{array}{l}\text { Average Computer Pen. Rate } \\
\text { Sample Size }\end{array}$ & $\begin{array}{c}20.29 \\
221 \\
\end{array}$ & $\begin{array}{c}20.84 \\
197 \\
\end{array}$ & $\begin{array}{c}23.56 \\
170 \\
\end{array}$ & $\begin{array}{c}17.72 \\
240 \\
\end{array}$ & $\begin{array}{c}15.17 \\
301 \\
\end{array}$ \\
\hline
\end{tabular}

Notes: (1) The dependent variable is the number of personal computers per 100 people. (2) Estimates account for country-level random effects. (3) Standard errors are reported below coefficient estimates. 
Table 3

Internet Penetration Rate Regressions (2002-2004)

\begin{tabular}{|c|c|c|c|c|c|}
\hline Explanatory Variables & (1) & (2) & $\begin{array}{l}\text { pecification } \\
\text { (3) }\end{array}$ & $(4)$ & (5) \\
\hline $\begin{array}{l}\text { Main telephone lines per } \\
100 \text { people }\end{array}$ & $\begin{array}{c}0.0889 \\
(0.1199)\end{array}$ & $\begin{array}{c}0.0971 \\
(0.1283)\end{array}$ & $\begin{array}{c}0.0759 \\
(0.1406)\end{array}$ & $\begin{array}{c}0.1263 \\
(0.1123)\end{array}$ & $\begin{array}{c}0.2163 \\
(0.1035)\end{array}$ \\
\hline $\begin{array}{l}\text { Monthly telephone } \\
\text { subscription charge }\end{array}$ & $\begin{array}{l}0.0370 \\
(0.0605)\end{array}$ & $\begin{array}{c}0.0308 \\
(0.0613)\end{array}$ & $\begin{array}{l}-0.0071 \\
(0.0782)\end{array}$ & & \\
\hline $\begin{array}{l}\text { Cost of three minute local } \\
\text { call }\end{array}$ & $\begin{array}{l}-3.9731 \\
(3.3398)\end{array}$ & $\begin{array}{l}-3.3835 \\
(3.3129)\end{array}$ & $\begin{array}{l}-3.7733 \\
(3.6419)\end{array}$ & & \\
\hline $\begin{array}{l}\text { Electric power consumption } \\
\text { (kwh per capita) }\end{array}$ & $\begin{array}{c}0.0008 \\
(0.0012)\end{array}$ & $\begin{array}{l}0.0009 \\
(0.0014)\end{array}$ & $\begin{array}{l}0.0015 \\
(0.0014)\end{array}$ & & \\
\hline $\begin{array}{l}\text { Population ages } 0-14 \\
\text { (\% of total) }\end{array}$ & $\begin{array}{c}0.4460 \\
(0.2690)\end{array}$ & $\begin{array}{c}0.5927 \\
(0.2947)\end{array}$ & $\begin{array}{c}0.4994 \\
(0.3222)\end{array}$ & $\begin{array}{c}0.3471 \\
(0.2192)\end{array}$ & $\begin{array}{c}0.1762 \\
(0.1921)\end{array}$ \\
\hline $\begin{array}{l}\text { Population ages } 65 \text { and } \\
\text { above (\% of total) }\end{array}$ & $\begin{array}{l}0.0248 \\
(0.5046)\end{array}$ & $\begin{array}{c}0.1791 \\
(0.5745)\end{array}$ & $\begin{array}{l}-0.1253 \\
(0.6029)\end{array}$ & $\begin{array}{l}-0.0283 \\
(0.4659)\end{array}$ & $\begin{array}{c}0.3354 \\
(0.4112)\end{array}$ \\
\hline Urban population (\% of total) & $\begin{array}{l}-0.0017 \\
(0.0693)\end{array}$ & $\begin{array}{c}0.0570 \\
(0.0774)\end{array}$ & $\begin{array}{c}0.0631 \\
(0.0780)\end{array}$ & $\begin{array}{c}0.0579 \\
(0.0583)\end{array}$ & $\begin{array}{c}0.0521 \\
(0.0476)\end{array}$ \\
\hline $\begin{array}{l}\text { Gross national income per } \\
\text { capita (000s) }\end{array}$ & $\begin{array}{l}0.9636 \\
(0.2810)\end{array}$ & $\begin{array}{l}0.7930 \\
(0.3125)\end{array}$ & $\begin{array}{l}0.6587 \\
(0.3304)\end{array}$ & $\begin{array}{c}1.0664 \\
(0.2383)\end{array}$ & $\begin{array}{c}0.7053 \\
(0.2136)\end{array}$ \\
\hline Years of schooling & $\begin{array}{c}0.9995 \\
(0.7368)\end{array}$ & $\begin{array}{c}0.9711 \\
(0.8043)\end{array}$ & $\begin{array}{l}1.3508 \\
(0.9152)\end{array}$ & $\begin{array}{c}0.6758 \\
(0.6340)\end{array}$ & \\
\hline Rule of law & $\begin{array}{l}5.9491 \\
(2.1681)\end{array}$ & $\begin{array}{l}5.2261 \\
(2.5006)\end{array}$ & $\begin{array}{l}8.7481 \\
(2.6257)\end{array}$ & $\begin{array}{l}2.3046 \\
(1.9584)\end{array}$ & $\begin{array}{c}2.3349 \\
(1.5837)\end{array}$ \\
\hline Trade in goods ( $\%$ of GDP) & $\begin{array}{c}0.0044 \\
(0.0195)\end{array}$ & $\begin{array}{c}0.0024 \\
(0.0246)\end{array}$ & $\begin{array}{l}-0.0144 \\
(0.0264)\end{array}$ & $\begin{array}{c}0.0069 \\
(0.0189)\end{array}$ & $\begin{array}{c}0.0171 \\
(0.0177)\end{array}$ \\
\hline Financial openness & & $\begin{array}{l}-0.4032 \\
(0.6757)\end{array}$ & $\begin{array}{l}-1.0225 \\
(0.7856)\end{array}$ & $\begin{array}{l}-0.1007 \\
(0.5471)\end{array}$ & $\begin{array}{c}0.6194 \\
(0.4938)\end{array}$ \\
\hline $\begin{array}{l}\text { Private credit by banks and } \\
\text { oth. fin. insts. / GDP }\end{array}$ & & $\begin{array}{l}5.8935 \\
(3.3235)\end{array}$ & & $\begin{array}{c}6.7487 \\
(3.0227)\end{array}$ & $\begin{array}{c}7.2865 \\
(2.8765)\end{array}$ \\
\hline $\begin{array}{l}\text { Stock market total value } \\
\text { traded / GDP }\end{array}$ & & & $\begin{array}{c}0.3267 \\
(1.9302)\end{array}$ & & \\
\hline Illiteracy rate & & & & & $\begin{array}{c}0.0307 \\
(0.0564)\end{array}$ \\
\hline $\begin{array}{l}\text { Average Internet Pen. Rate } \\
\text { Sample Size }\end{array}$ & $\begin{array}{c}21.58 \\
235\end{array}$ & $\begin{array}{c}22.10 \\
211\end{array}$ & $\begin{array}{c}25.16 \\
180\end{array}$ & $\begin{array}{l}18.33 \\
266\end{array}$ & $\begin{array}{c}16.02 \\
331\end{array}$ \\
\hline
\end{tabular}

Notes: (1) The dependent variable is the number of Internet users per 100 people. (2) Estimates account for countrylevel random effects. (3) Standard errors are reported below coefficient estimates. 
Table 4

Technology Penetration Rate Regressions by Country Type (2002-2004)

Specification

\begin{tabular}{lcccc} 
Explanatory Variables & $(1)$ & $(2)$ & $(4)$ & $(5)$ \\
\hline Dependent variable & Computer & Computer & Internet & Internet \\
Country type & Developing & Other & Developing & Other \\
Main telephone lines per & 0.1218 & 0.4972 & 0.0238 & 0.2182 \\
$\quad$ 100 people & $(0.0729)$ & $(0.2579)$ & $(0.1669)$ & $(0.2372)$ \\
Monthly telephone & -0.0062 & -0.2129 & 0.0380 & -0.1226 \\
$\quad$ subscription charge & $(0.0157)$ & $(0.3255)$ & $(0.0364)$ & $(0.2838)$ \\
Cost of three minute local & -1.0552 & -11.2444 & -5.9613 & -6.2905 \\
$\quad$ call & $(1.9882)$ & $(6.5020)$ & $(4.6878)$ & $(4.6203)$ \\
Electric power consumption & 0.0004 & 0.0029 & 0.0013 & 0.0049 \\
$\quad$ kwh per capita) & $(0.0006)$ & $(0.0040)$ & $(0.0011)$ & $(0.0039)$ \\
Population ages 0-14 & 0.1425 & -0.5322 & 0.3093 & -0.2622 \\
$\quad$ (\% of total) & $(0.1360)$ & $(1.1073)$ & $(0.2660)$ & $(1.1558)$ \\
Population ages 65 and & 0.3711 & -1.2534 & 1.3834 & 0.0706 \\
$\quad$ above (\% of total) & $(0.3912)$ & $(1.1520)$ & $(0.7778)$ & $(1.1499)$ \\
Urban population (\% of total) & 0.0141 & -0.1220 & 0.0321 & 0.1091 \\
& $(0.0363)$ & $(0.1916)$ & $(0.0707)$ & $(0.2017)$ \\
Gross national income per & 0.8475 & 0.6296 & 0.7354 & -0.9214 \\
$\quad$ capita (000s) & $(0.2692)$ & $(0.5774)$ & $(0.5574)$ & $(0.5808)$ \\
Years of schooling & -0.2030 & 3.1622 & -0.7503 & 1.8903 \\
& $(0.4063)$ & $(1.6624)$ & $(0.7792)$ & $(1.6742)$ \\
Rule of law & 0.9200 & 8.6145 & 4.3273 & 16.4094 \\
& $(0.8653)$ & $(6.2832)$ & $(1.7650)$ & $(6.4209)$ \\
Trade in goods (\% of GDP) & 0.0242 & 0.0653 & 0.0746 & -0.0131 \\
& $(0.0133)$ & $(0.0458)$ & $(0.0257)$ & $(0.0410)$ \\
Financial openness & 0.3019 & -0.1688 & 0.2163 & -2.4526 \\
& $(0.2254)$ & $(2.6427)$ & $(0.4557)$ & $(2.2238)$ \\
Private credit by banks and & -1.6635 & 2.7431 & -0.2028 & 7.5631 \\
oth. fin. insts. / GDP & $(1.5430)$ & $(6.3784)$ & $(3.1659)$ & $(5.9305)$ \\
Average dependent variable & 4.85 & 43.26 & 7.49 & 43.76 \\
Sample Size & 115 & 82 & 126 & 85 \\
\hline
\end{tabular}

Notes: (1) The dependent variable is the number of personal computers per 100 people. (2) Estimates account for country-level random effects. (3) Standard errors are reported below coefficient estimates. 
Table 5

Computer Penetration Rate Decompositions Relative to Developed Country Total (2002-2004)

\begin{tabular}{|c|c|c|c|c|c|c|c|}
\hline & $\begin{array}{l}\text { Developing } \\
\text { Total }\end{array}$ & Brazil & China & Indonesia & India & Mexico & Nigeria \\
\hline Computer penetration rate gap & 47.3 & 41.5 & 46.9 & 49.2 & 49.5 & 40.9 & 49.8 \\
\hline \multicolumn{8}{|l|}{ Contribution from: } \\
\hline Main telephone lines per 100 people & 16.1 & 11.7 & 12.8 & 18.4 & 18.4 & 14.1 & 22.2 \\
\hline Monthly telephone subscription charge & -0.1 & 0.1 & -0.1 & -0.1 & 0.0 & 0.1 & 0.2 \\
\hline Cost of three minute local call & 0.3 & 0.2 & 0.2 & 0.0 & 0.1 & 0.6 & 1.2 \\
\hline Electric power consumption (kwh per capita) & -4.5 & -3.6 & -4.2 & -4.9 & -4.9 & -3.7 & -5.2 \\
\hline Population ages $0-14$ (\% of total) & -8.4 & -5.8 & -3.3 & -7.2 & -9.0 & -8.9 & -12.9 \\
\hline Population ages 65 and above (\% of total) & -7.9 & -7.8 & -6.3 & -8.3 & -8.1 & -8.0 & -12.3 \\
\hline Urban population (\% of total) & -2.1 & 0.3 & -2.3 & -1.9 & -2.8 & -0.2 & -1.0 \\
\hline Gross national income per capita (000s) & 43.7 & 37.7 & 42.1 & 45.1 & 45.8 & 35.1 & 50.7 \\
\hline Years of schooling & 6.1 & 6.7 & 4.9 & 6.5 & 6.4 & 3.7 & \\
\hline Rule of law & 5.3 & 4.8 & 5.2 & 6.6 & 4.1 & 4.9 & 9.3 \\
\hline Trade in goods (\% of GDP) & -0.1 & 0.3 & -0.4 & -0.1 & 0.4 & -0.3 & -0.1 \\
\hline Financial openness & -0.3 & -0.2 & -0.3 & -0.1 & -0.3 & -0.2 & 0.4 \\
\hline $\begin{array}{l}\text { Private credit by banks and oth. fin. insts. / } \\
\text { GDP }\end{array}$ & 0.4 & 0.4 & & 0.4 & 0.4 & 0.4 & 0.5 \\
\hline
\end{tabular}


Table 6

Internet Penetration Rate Decompositions Relative to Developed Country Total (2002-2004)

\begin{tabular}{|c|c|c|c|c|c|c|c|}
\hline & $\begin{array}{c}\text { Developing } \\
\text { Total }\end{array}$ & Brazil & China & Indonesia & India & Mexico & Nigeria \\
\hline Internet penetration rate gap & 42.7 & 37.2 & 41.4 & 43.3 & 45.2 & 35.4 & 46.6 \\
\hline \multicolumn{8}{|l|}{ Contribution from: } \\
\hline Main telephone lines per 100 people & 4.3 & 3.2 & 4.3 & 5.0 & 5.0 & 3.8 & 6.6 \\
\hline Monthly telephone subscription charge & 0.1 & -0.2 & 0.3 & 0.2 & 0.0 & -0.1 & 0.5 \\
\hline Cost of three minute local call & 0.2 & 0.1 & 0.1 & 0.0 & 0.0 & 0.4 & 0.8 \\
\hline Electric power consumption (kwh per capita) & 4.5 & 3.6 & 4.2 & 4.9 & 4.9 & 3.7 & 5.2 \\
\hline Population ages $0-14$ (\% of total) & -7.7 & -5.3 & -2.7 & -6.6 & -8.2 & -8.1 & -12.4 \\
\hline Population ages 65 and above (\% of total) & 1.6 & 1.6 & -0.6 & 1.7 & 1.7 & 1.7 & 0.9 \\
\hline Urban population (\% of total) & 2.1 & -0.3 & 1.5 & 1.9 & 2.8 & 0.2 & 2.6 \\
\hline Gross national income per capita (000s) & 20.6 & 17.8 & 24.3 & 21.3 & 21.6 & 16.6 & 24.3 \\
\hline Years of schooling & 4.6 & 5.0 & 3.8 & 4.9 & 4.7 & 2.8 & \\
\hline Rule of law & 9.7 & 8.8 & 11.2 & 12.1 & 7.5 & 8.9 & 16.1 \\
\hline Trade in goods (\% of GDP) & 0.0 & 0.0 & 0.0 & 0.0 & 0.0 & 0.0 & 0.0 \\
\hline Financial openness & -1.2 & -1.0 & -1.5 & -0.5 & -1.4 & -0.8 & -0.8 \\
\hline $\begin{array}{l}\text { Private credit by banks and oth. fin. insts. / } \\
\text { GDP }\end{array}$ & 6.3 & 6.0 & & 6.9 & 6.2 & 7.1 & 7.2 \\
\hline
\end{tabular}


Table 7: Technology Penetration Dynamics

\begin{tabular}{|c|c|c|c|c|c|c|}
\hline Dependent Variable & \multicolumn{6}{|c|}{ Specification } \\
\hline & Computer & Computer & Computer & Internet & Internet & Internet \\
\hline Lagged log technology & -0.0416 & -0.0407 & -0.061 & -0.0972 & -0.0988 & -0.0824 \\
\hline penetration level & $(0.0206)$ & $(0.0141)$ & $(0.0160)$ & $(0.0247)$ & $(0.0173)$ & $(0.0167)$ \\
\hline Main telephone lines per & -0.033 & -0.0151 & -0.0313 & 0.0771 & 0.0642 & 0.0642 \\
\hline 100 people & $(0.0250)$ & $(0.0174)$ & $(0.0202)$ & $(0.0363)$ & $(0.0248)$ & $(0.0236)$ \\
\hline Monthly telephone & 0.0427 & & & 0.004 & & \\
\hline subscription charge & $(0.0143)$ & & & $(0.0199)$ & & \\
\hline Cost of three minute local & -0.0412 & & & -0.0062 & & \\
\hline call & $(0.0138)$ & & & $(0.0192)$ & & \\
\hline Electric power consumption & -0.0092 & & & -0.0072 & & \\
\hline (kwh per capita) & $(0.0209)$ & & & $(0.0257)$ & & \\
\hline Population ages $0-14$ & -0.1766 & -0.1235 & -0.0933 & 0.0198 & 0.0615 & 0.0939 \\
\hline (\% of total) & $(0.1166)$ & $(0.1090)$ & $(0.1114)$ & $(0.1424)$ & $(0.1362)$ & $(0.1172)$ \\
\hline Population ages 65 and & -0.1068 & -0.0482 & -0.0423 & 0.0629 & 0.0736 & 0.0688 \\
\hline above $(\%$ of total) & $(0.0765)$ & $(0.0589)$ & $(0.0616)$ & $(0.0928)$ & $(0.0738)$ & $(0.0660)$ \\
\hline Urban population ( $\%$ of total) & -0.0365 & 0.0215 & 0.0357 & 0.045 & 0.0575 & 0.0555 \\
\hline & $(0.0459)$ & $(0.0297)$ & $(0.0329)$ & $(0.0650)$ & $(0.0386)$ & $(0.0344)$ \\
\hline Gross national income per & 0.0648 & 0.0358 & 0.0859 & -0.0761 & -0.0517 & -0.0977 \\
\hline capita (000s) & $(0.0377)$ & $(0.0299)$ & $(0.0361)$ & $(0.0513)$ & $(0.0384)$ & $(0.0372)$ \\
\hline Years of schooling & 0.0214 & -0.0034 & 0.0064 & -0.0707 & -0.0019 & 0.0233 \\
\hline & $(0.0415)$ & $(0.0293)$ & $(0.0494)$ & $(0.0579)$ & $(0.0360)$ & $(0.0551)$ \\
\hline Rule of law & 0.0042 & -0.0276 & -0.0207 & -0.0049 & -0.0308 & -0.0121 \\
\hline & $(0.0274)$ & $(0.0196)$ & $(0.0214)$ & $(0.0347)$ & $(0.0257)$ & $(0.0242)$ \\
\hline Trade in goods ( $\%$ of GDP) & -0.0007 & -0.002 & 0.0037 & 0.0234 & 0.0318 & 0.0201 \\
\hline & $(0.0199)$ & $(0.0172)$ & $(0.0181)$ & $(0.0262)$ & $(0.0216)$ & $(0.0201)$ \\
\hline Financial openness & 0.0006 & -0.0005 & 0.002 & 0.0139 & 0.0136 & 0.0108 \\
\hline & $(0.0082)$ & $(0.0066)$ & $(0.0076)$ & $(0.0105)$ & $(0.0087)$ & $(0.0085)$ \\
\hline Private credit by deposit money & & & & & & \\
\hline banks and oth. fin. insts. / GDP & 0.0174 & 0.0431 & & 0.0205 & 0.0198 & \\
\hline & $(0.0201)$ & $(0.0163)$ & & $(0.0276)$ & $(0.0211)$ & \\
\hline Stock market total value & & & 0.0057 & & & 0.014 \\
\hline traded/GDP & & & $(0.0043)$ & & & $(0.0045)$ \\
\hline Observations & 56 & 73 & 60 & 63 & 82 & 66 \\
\hline R-squared & 0.55 & 0.36 & 0.5 & 0.78 & 0.72 & 0.79 \\
\hline
\end{tabular}

Notes: (1) The dependent variable is the 5 year difference in the log number of personal computers per 100 people, in columns 1-3; and 5 year difference in the log number of internet users per 100 people in columns 3-4. (2) Standard errors are reported below coefficient estimates. 
Table 8: Technology Penetration Dynamics by Country Type Specification

(1) (2) (3) $\quad$ (3)

\begin{tabular}{|c|c|c|c|c|c|c|}
\hline $\begin{array}{l}\text { Dependent Variable } \\
\text { Country Type }\end{array}$ & $\begin{array}{l}\text { Computer } \\
\text { Developing }\end{array}$ & $\begin{array}{l}\text { Computer } \\
\text { Other }\end{array}$ & $\begin{array}{l}\text { Computer } \\
\text { Other }\end{array}$ & $\begin{array}{c}\text { Internet } \\
\text { Developing }\end{array}$ & $\begin{array}{c}\text { Internet } \\
\text { Developing }\end{array}$ & $\begin{array}{c}\text { Internet } \\
\text { Other }\end{array}$ \\
\hline $\begin{array}{l}\text { Lagged log technology } \\
\text { penetration level }\end{array}$ & $\begin{array}{l}-0.0394 \\
(0.0310)\end{array}$ & $\begin{array}{c}0.0037 \\
(0.0831)\end{array}$ & $\begin{array}{c}0.0719 \\
(0.0400)\end{array}$ & $\begin{array}{l}-0.1183 \\
(0.0395)\end{array}$ & $\begin{array}{l}-0.0836 \\
(0.0272)\end{array}$ & $\begin{array}{l}-0.0958 \\
(0.0391)\end{array}$ \\
\hline $\begin{array}{l}\text { Main telephone lines per } \\
100 \text { people }\end{array}$ & $\begin{array}{l}-0.0444 \\
(0.0407)\end{array}$ & $\begin{array}{l}-0.0103 \\
(0.1414)\end{array}$ & $\begin{array}{c}0.0014 \\
(0.0673)\end{array}$ & $\begin{array}{c}0.1168 \\
(0.0565)\end{array}$ & $\begin{array}{l}0.0702 \\
(0.0369)\end{array}$ & $\begin{array}{c}0.0609 \\
(0.1239)\end{array}$ \\
\hline $\begin{array}{l}\text { Monthly telephone } \\
\text { subscription charge }\end{array}$ & $\begin{array}{c}0.0466 \\
(0.0225)\end{array}$ & $\begin{array}{c}0.0313 \\
(0.0666)\end{array}$ & & $\begin{array}{l}-0.0034 \\
(0.0321)\end{array}$ & & $\begin{array}{c}0.035 \\
(0.0591)\end{array}$ \\
\hline $\begin{array}{l}\text { Cost of three minute local } \\
\text { call }\end{array}$ & $\begin{array}{c}-0.046 \\
(0.0227)\end{array}$ & $\begin{array}{c}0.0024 \\
(0.0415)\end{array}$ & & $\begin{array}{c}0.0025 \\
(0.0321)\end{array}$ & & $\begin{array}{l}-0.0095 \\
(0.0395)\end{array}$ \\
\hline $\begin{array}{l}\text { Electric power consump. } \\
\qquad \text { (kwh per capita) }\end{array}$ & $\begin{array}{c}-0.019 \\
(0.0274)\end{array}$ & $\begin{array}{c}0.4988 \\
(0.4418)\end{array}$ & & $\begin{array}{l}-0.0049 \\
(0.0355)\end{array}$ & & $\begin{array}{c}0.4856 \\
(0.4088)\end{array}$ \\
\hline $\begin{array}{l}\text { Population ages } 0-14 \\
\text { (\% of total) }\end{array}$ & $\begin{array}{l}-0.3314 \\
(0.1957)\end{array}$ & $\begin{array}{l}-0.0661 \\
(0.2192)\end{array}$ & $\begin{array}{l}-0.1561 \\
(0.1295)\end{array}$ & $\begin{array}{l}-0.0723 \\
(0.2592)\end{array}$ & $\begin{array}{c}0.1475 \\
(0.2173)\end{array}$ & $\begin{array}{c}0.0214 \\
(0.1266)\end{array}$ \\
\hline $\begin{array}{c}\text { Population ages } 65 \text { and } \\
\text { above (\% of total) } \\
\text { Urban population (\% of }\end{array}$ & $\begin{array}{l}-0.1919 \\
(0.1140)\end{array}$ & $\begin{array}{l}-0.0933 \\
(0.2421)\end{array}$ & $\begin{array}{l}-0.1559 \\
(0.1352)\end{array}$ & $\begin{array}{c}0.0423 \\
(0.1494)\end{array}$ & $\begin{array}{c}0.0847 \\
(0.1139)\end{array}$ & $\begin{array}{c}0.0394 \\
(0.1374)\end{array}$ \\
\hline total) & $\begin{array}{l}-0.0498 \\
(0.0677)\end{array}$ & $\begin{array}{c}0.0814 \\
(0.1177)\end{array}$ & $\begin{array}{c}0.0997 \\
(0.0698)\end{array}$ & $\begin{array}{c}0.0688 \\
(0.1009)\end{array}$ & $\begin{array}{c}0.0504 \\
(0.0511)\end{array}$ & $\begin{array}{c}0.0399 \\
(0.0908)\end{array}$ \\
\hline $\begin{array}{c}\text { Gross national income } \\
\text { per capita (000s) }\end{array}$ & $\begin{array}{c}0.0949 \\
(0.0602)\end{array}$ & $\begin{array}{l}-0.1801 \\
(0.1640)\end{array}$ & $\begin{array}{l}-0.0899 \\
(0.0832)\end{array}$ & $\begin{array}{l}-0.1323 \\
(0.0863)\end{array}$ & $\begin{array}{l}-0.1136 \\
(0.0599)\end{array}$ & $\begin{array}{l}-0.1577 \\
(0.1696)\end{array}$ \\
\hline Years of schooling & $\begin{array}{c}0.001 \\
(0.0585)\end{array}$ & $\begin{array}{l}-0.0271 \\
(0.1326)\end{array}$ & $\begin{array}{l}-0.1486 \\
(0.1030)\end{array}$ & $\begin{array}{l}-0.0671 \\
(0.0823)\end{array}$ & $\begin{array}{c}0.0531 \\
(0.0822)\end{array}$ & $\begin{array}{l}-0.2011 \\
(0.1222)\end{array}$ \\
\hline Rule of law & $\begin{array}{c}0.0306 \\
(0.0425)\end{array}$ & $\begin{array}{l}-0.0693 \\
(0.0698)\end{array}$ & $\begin{array}{l}-0.0736 \\
(0.0345)\end{array}$ & $\begin{array}{l}-0.0139 \\
(0.0568)\end{array}$ & $\begin{array}{l}-0.0044 \\
(0.0365)\end{array}$ & $\begin{array}{l}-0.0109 \\
(0.0736)\end{array}$ \\
\hline $\begin{array}{l}\text { Trade in goods } \\
\text { (\% of GDP) }\end{array}$ & $\begin{array}{l}-0.0027 \\
(0.0360)\end{array}$ & $\begin{array}{l}-0.0187 \\
(0.0269)\end{array}$ & $\begin{array}{c}0.0064 \\
(0.0201)\end{array}$ & $\begin{array}{c}0.0644 \\
(0.0498)\end{array}$ & $\begin{array}{c}0.0309 \\
(0.0414)\end{array}$ & $\begin{array}{l}-0.0172 \\
(0.0289)\end{array}$ \\
\hline Financial openness & $\begin{array}{c}0.01 \\
(0.0122)\end{array}$ & $\begin{array}{c}0.0503 \\
(0.0456)\end{array}$ & $\begin{array}{c}0.0411 \\
(0.0240)\end{array}$ & $\begin{array}{c}0.0152 \\
(0.0156)\end{array}$ & $\begin{array}{c}0.0089 \\
(0.0124)\end{array}$ & $\begin{array}{l}-0.0072 \\
(0.0378)\end{array}$ \\
\hline $\begin{array}{l}\text { Private credit by deposit } \\
\text { money banks and oth. fin. } \\
\text { insts. / GDP }\end{array}$ & $\begin{array}{c}0.0019 \\
(0.0290)\end{array}$ & $\begin{array}{c}0.0555 \\
(0.0736)\end{array}$ & $\begin{array}{l}-0.0071 \\
(0.0422)\end{array}$ & $\begin{array}{c}0.0137 \\
(0.0409)\end{array}$ & & $\begin{array}{c}0.006 \\
(0.0705)\end{array}$ \\
\hline $\begin{array}{l}\text { Stock market total value } \\
\text { traded/GDP }\end{array}$ & & & & & $\begin{array}{c}0.0144 \\
(0.0064)\end{array}$ & \\
\hline Observations & 36 & 20 & 23 & 41 & 41 & 22 \\
\hline R-squared & 0.56 & 0.76 & 0.59 & 0.62 & 0.63 & 0.87 \\
\hline
\end{tabular}

Notes: (1) The dependent variable is the 5 year difference in the log number of personal computers per 100 people, in columns 1-3; and 5 year difference in the log number of internet users per 100 people in columns 3-4. (2) Standard errors are reported below coefficient estimates. 